\title{
23. MINERALOGY, PETROLOGY, AND DIAGENESIS OF SEDIMENTS AT SITE 530, SOUTHEAST ANGOLA BASIN ${ }^{1}$
}

\author{
Dorrik A. V. Stow and John Miller, Grant Institute of Geology, University of Edinburgh, \\ Edinburgh, Scotland, EH9 3JW, United Kingdom
}

\begin{abstract}
The sediment source, depositional environment, and diagenetic history of post-Albian sediments at Site 530 are interpreted on the basis of their clay mineralogy, sand-silt petrology, and cathodoluminescent properties. The vertical distribution of six main components (diatoms, carbonate, quartz, feldspar, volcaniclasts, and clays) and five main clay minerals (smectite, mixed-layers, illite, chlorite, and kaolinite) characterize six distinct periods of basin evolution: (1) Albian-Coniacian, terrigenous (quartz, chlorite) input into black-shale basin; (2) Santonian-Campanian, volcanogenic turbidites (smectite dominant) with redeposited carbonates from the Walvis Ridge and African margin; (3) early Maestrichtian, transitional period with feldspathic turbidites; (4) late Maestrichtian-Eocene, calciturbidites from Walvis Ridge and African margin carbonate platforms; no change across Cretaceous-Tertiary boundary; (5) Oligocene-Miocene, pelagic clays with dominant illite, no calciturbidites, minor turbidite or contourite siltstones, and (6) MioceneRecent, biogenic turbidites from Walvis Ridge: organic-rich pelagites, related to Benguela upwelling, with increased kaolinite reflecting low-latitude weathering. Post-depositional diagenesis involved different phases and types of carbonate cementation, minor silicification, and the alteration of volcanics to smectite clays.
\end{abstract}

\section{INTRODUCTION}

The post-Albian sediments cored at Site 530 in the S.E. Angola Basin comprise a varied suite of clastics, volcaniclastics, and carbonates grouped into eight distinct lithologic units (see Fig. 1, Plates 1, 2, and Site 530 summary, this volume). Detailed facies descriptions, geochemical and other analyses of these sediments are reported elsewhere in this volume (Stow; Stow and Dean; Dean and Parduhn; Dean et al.; Maillot and Robert). The present chapter concentrates on the petrology and diagenesis of the coarser-grained silt and sand-size sediments and clay mineralogy throughout the section, and attempts to interpret these in terms of sediment source, depositional processes and environment, and post-depositional changes. In addition to standard petrographic techniques (see below), we have employed cathodoluminescence microscopy, and this has proved invaluable in revealing aspects of composition, texture, diagenesis, and grain provenance that would not otherwise have been available.

\section{METHODS}

General features of the sediments, including degree of lithification and sedimentary structures, were described from the cores on shipboard and confirmed on samples in the laboratory. About 60 thin sections were made for detailed petrography of the clastics and carbonates; all of these had to be vacuum-impregnated. Relative grain percentages were estimated visually by comparison with standardized grain percent charts. Accuracy of estimation was checked by point counting on several samples and found to be reliable. Numerous smear slides of the sand fraction within the younger unconsolidated or semiconsolidated sediments were examined (mainly on shipboard) and relative percentages of components again estimated.

\footnotetext{
${ }^{1}$ Hay, W. W., Sibuet, J.-C., et al., Init. Repts. DSDP, 75: Washington (U.S. Govt.
}

A further 15 thin sections were prepared for cathodoluminescence by polishing both upper and lower surfaces and mounting in Versamid cement. Lower surface polish is not itself required for luminescence, but it does improve the optical qualities of the thin section-though this is not so apparent with such poorly consolidated material. Sections were examined in a Nuclide ELM 2A Luminoscope at 0.05 Torr at voltages between 12 and $15 \mathrm{kV}$ and beam currents of up to $0.1 \mathrm{~mA}$. The Luminoscope was mounted on an Olympus POS microscope and photographs taken on an Olympus OM2A photo-attachment using Ilford FP4 monochrome film uprated to 200 ASA by compensating development. A good general account of the use of cathodoluminescence in geology is given by Nickel (1978). Results are reported according to the standards proposed by Marshall (1978).

One hundred samples of various lithologies were prepared for $\mathrm{x}$-ray diffraction analysis (XRD) of the clay mineralogy. The fine fraction (less than $2 \mu \mathrm{m}$ ) was separated by ultrasonic treatment and settling. Orientated aggregates were made on glass slides. Two XRD traces were run for most samples, first untreated, then glycolated; a third slow scan run was made selectively to separate the chlorite and kaolinite peaks between 24 and $26^{\circ} 2 \theta$. Focussed copper $\mathrm{K} \alpha$ radiation was used throughout at a normal scan speed of $1^{\circ} 2 \theta$ per minute.

The main clay minerals recognized were kaolinite, chlorite, illite, smectite, and irregular mixed-layer species (Figs. 2 and 3). Other minerals included quartz, feldspars, calcite and rare dolomite, pyrite, attapulgite, and zeolites. Semiquantitative analyses were based on planimeter measurements of peak areas of glycolated samples, using weighting factors of kaolinite-chlorite $(\times 2)$, illite $(\times 4)$, smectite $(\times 1)$, and mixed-layers $(\times 1)$ after Biscaye (1965). Where referred to in this text, a clay percentage is relative to the total clay mineral fraction. Peak heights only were measured for the other minerals.

\section{PETROLOGY AND DIAGENESIS}

Bulk petrological composition of the coarser-grained sediments throughout the section at Site 530 is shown in Figure 1. Six main components (diatoms, carbonate, quartz, feldspar, volcanics, and clay) have been used to characterize the different lithological units. In lithologic Units 8 and 3 , only a few scattered thin siltstones have been studied; these are interbedded with dominant mudstones and marlstones. In Units 2 and 1 there are few if any distinct sand layers, so that whole-sediment petrology for these units is shown. Otherwise, thin sections 

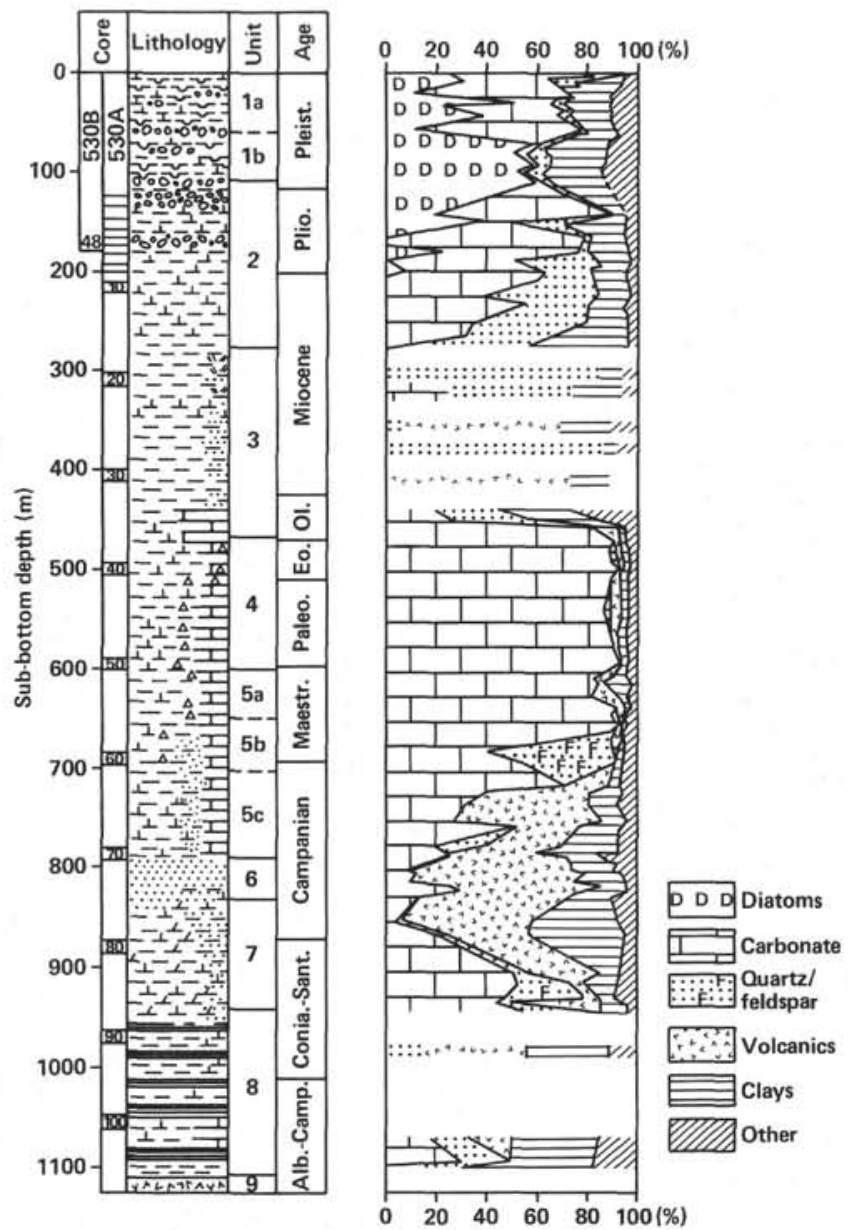

Figure 1. Bulk petrology of the coarser-grained (silt and sand-sized) sediments at Site 530, showing relative percentages of the six main components in relation to the lithologic units and stratigraphy (see site summary, this volume). (Revisions of stratigraphic ages are given in Steinmetz et al., this volume).

were made from all distinctive coarse-grained lithologies, most of which are turbidites (Stow, this volume), and their petrographic characters are described below (see also Plate 1).

\section{Quartz-Silt Turbidites (Plate 1)}

Most of Unit 8 (about $160 \mathrm{~m}$ thick) comprises red and green mudstones and marlstones interbedded with organic carbon-rich black shales. These sediments represent pelagic, hemipelagic, and minor turbiditic deposition in a basinal setting. Thin and very thin-bedded siltstones and rare sandstones form a small percentage of the whole unit, being more common in the lowest $50 \mathrm{~m}$, and are mostly turbidites.

These coarser-grained layers are quartz-rich (15-40\%) and clayey (20-50\%), but also contain up to $30 \%$ carbonate and up to $35 \%$ volcanic debris. Other minerals include opaques (up to $10 \%$, particularly pyrite), feldspars, glauconite, micas, and organic material. The carbonate occurs as calcite spar or microspar cement with some identifiable bioclasts, including foraminifers and fragments of Inoceramus. Carbonate shows an overall decrease in abundance up-section with a concomitant increase in volcanogenics (see Site 530 summary chapter, this volume).

\section{Feldspathic Sandstones (Plates 1, 7)}

Near the base of lithologic Unit 7 and in Subunit 5b, there are thin-bedded, gray-colored, carbonate-cemented feldspathic sandstones, which were clearly introduced to the basin by turbidity currents (Plate 1). These are interbedded with carbonate turbidites.

In both units, the feldspars vary between 15 and $40 \%$ of the noncarbonate grains (i.e., 5-20\% of the bulk sample) (Plate 7, Figs. 5, 6). They are typically angular or lath-shaped, very fresh, and mostly devoid of twinning, although microcline is present, together with plagioclase and orthoclase. The untwinned grains are easily mistaken for quartz under transmitted light, but stand out clearly as bright blue under polarized cathodoluminescence. This luminescence is attributed to Ti-activation of the lattice (Mariano et al., 1973). About 5\% of the feldspars luminesce a bright apple-green color, although in transmitted light they cannot be distinguished from the rest of the feldspar population. Geake et al. (1971) have demonstrated that green luminescence could be induced in labradorite by doping with $\mathrm{Mn}^{2+}$. The causes of luminescence in the samples from Hole 530A are not known.

The quartz grains in the feldspathic sandstones are clear, monocrystalline, and usually very angular or shardlike (e.g., Plate 7, Fig. 6). They show a dull violet cathodoluminescence which becomes brown-red after heating a few minutes in the electron beam. This violet luminescence and attendant temperature sensitivity is characteristic of plutonic or volcanically derived quartz (Zinkernagel, 1978). Some of the quartz grains are rich in carbonate inclusions, revealed under luminescence as red speckles. Accessory minerals include biotite and zircon.

Bioclasts are not easily seen in these sediments with transmitted light, but under cathodoluminescence wellsorted foraminifers, echinoderm fragments, and comminuted inoceramid shell prisms are apparent. Some of these bioclasts may have been derived from shallow water, others picked up during transport. The calcite spar cement is uniformly brightly luminescent and consists of a single cement generation, forming mainly as a syntaxial overgrowth on echinoderm and inoceramid prism bioclasts as a preferential substrate.

The cause of luminescence in calcite is generally agreed to be due to the presence of $\mathrm{Mn}^{2+}$ as an activator, with the $\mathrm{Mn} / \mathrm{Fe}$ ratio controlling luminescent intensity (Frank, et al., 1982). However, Machel (1982) has suggested that other ions (mainly $\mathrm{Ce}$ and $\mathrm{Pb}$ ) may also be activators. The chemistry of carbonate cements in the Site 530 sediments is under further investigation by Miller and will be reported elsewhere. Pressure solution resulting from compaction of the sediments is clearly seen under luminescence: feldspar or quartz grains having stylolitic contacts with bioclasts. There is some corrosion of the quartz grains by calcite cement. At least some of the carbonate for the pore-filling cement may have been released from bioclasts by stylolitization. 

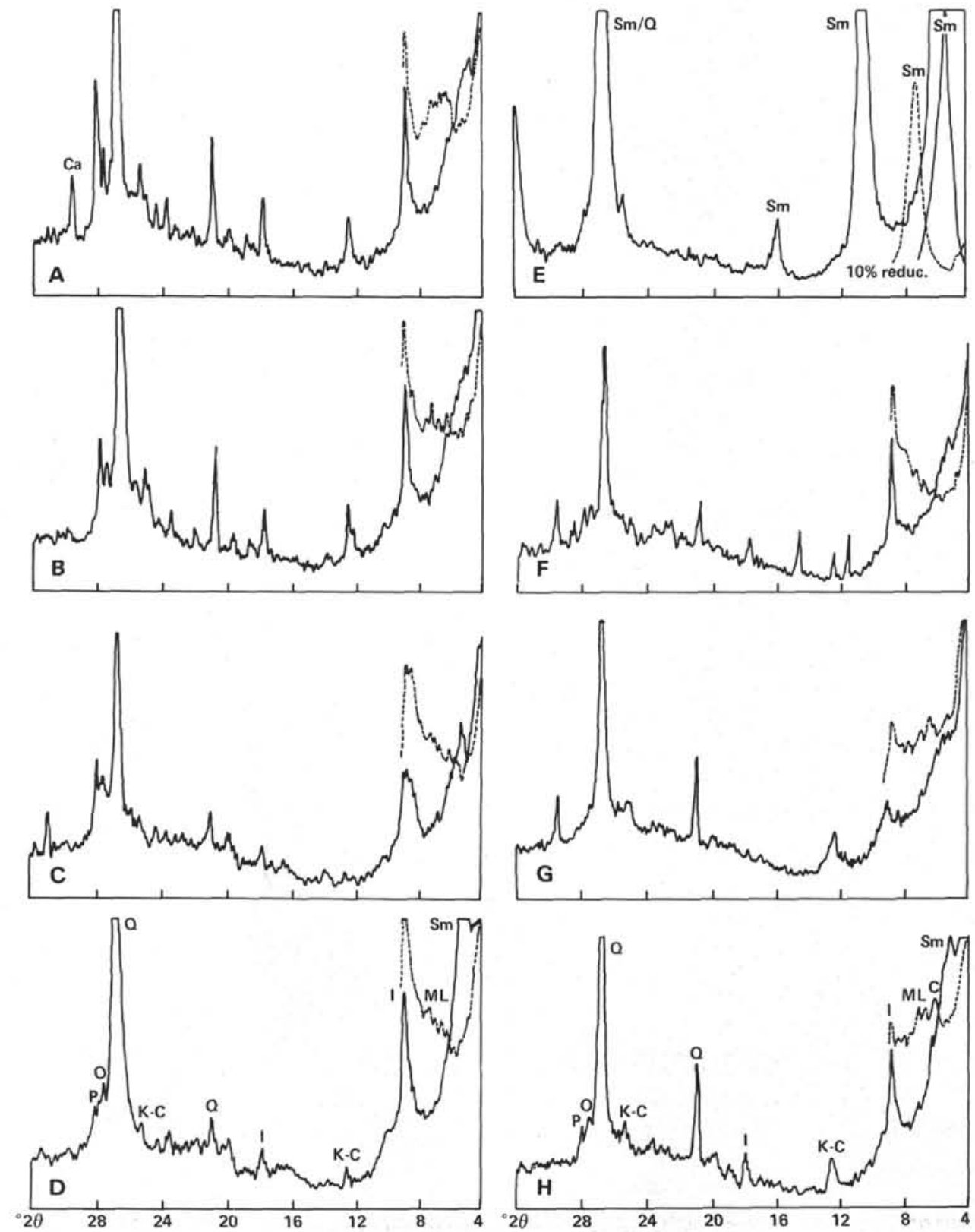

Figure 2. X-ray diffraction tracings of selected samples from Hole 530A. A. Sample 530A-15-5, $82 \mathrm{~cm}$ (Unit 2) light gray marl; B. Sample 530A-35-3, $75 \mathrm{~cm}$ (Unit 3) red mudstone; C. Sample 530A-38-1, $39 \mathrm{~cm}$ (Unit 4) light gray mudstone; D. Sample 530A-5-1, $69 \mathrm{~cm}$ (Unit 5) gray mudstone; E. Sample $530 \mathrm{~A}-73-2,100 \mathrm{~cm}$ (Unit 6) green volcanogenic sandstone; F. Sample 530A-90-3, $62 \mathrm{~cm}$ (Unit 8) black shale; G. Sample 530A-103-4, $142 \mathrm{~cm}$ (Unit 8) red mudstone; H. Sample 530A-105-4, $31 \mathrm{~cm}$ (Unit 8) green mudstone. Solid tracing is of glycolated sample; dashed tracing is of nonglycolated sample. Both traces in (E) have been reduced tenfold over the smectite peak at low $2 \theta$ angles. Identification of peaks is shown on traces $(\mathrm{D})$ and $(\mathrm{H})$ and where appropriate.

Note: $\mathrm{Q}=$ quartz; $\mathrm{Sm}=$ smectite; $\mathrm{ML}=$ mixed layer clays; $\mathrm{K}-\mathrm{C}=$ kaolinite + chlorite $\mathrm{P}=$ plagioclase; $\mathrm{O}=$ orthoclase; $\mathrm{I}=$ illite; $\mathrm{C}=$ chlorite.

\section{Volcanogenic Sandstones (Plates 1, 4, 5)}

About $250 \mathrm{~m}$ of section from Unit 7 to Subunit $5 \mathrm{c}$ (Fig. 1) reveals a major influx of volcanogenic turbidites into the S.E. Angola basinal sediments. This began with thin-bedded siltstone and mudstone turbidites (Plate 1, Figs. 3, 4), which thicken and coarsen upwards through Unit 7 and reach their maximum development $(95 \%$ of the section, bed thickness up to $3.5 \mathrm{~m}$ ) in Unit 6 . They then decrease gradually in abundance upsection through Unit 5c.

The two dominant components are volcaniclasts (30$60 \%$ ) and carbonate $(5-45 \%)$. Carbonate is relatively common towards the base of Unit 7 and then again in Unit 5c where it is commonly closely interlaminated with the darker-colored volcanogenic material (Plate 4, Fig. 5; Plate 5, Figs. 3-6). The volcanic debris is mostly glassy and highly altered to clays and iron oxides. Some 

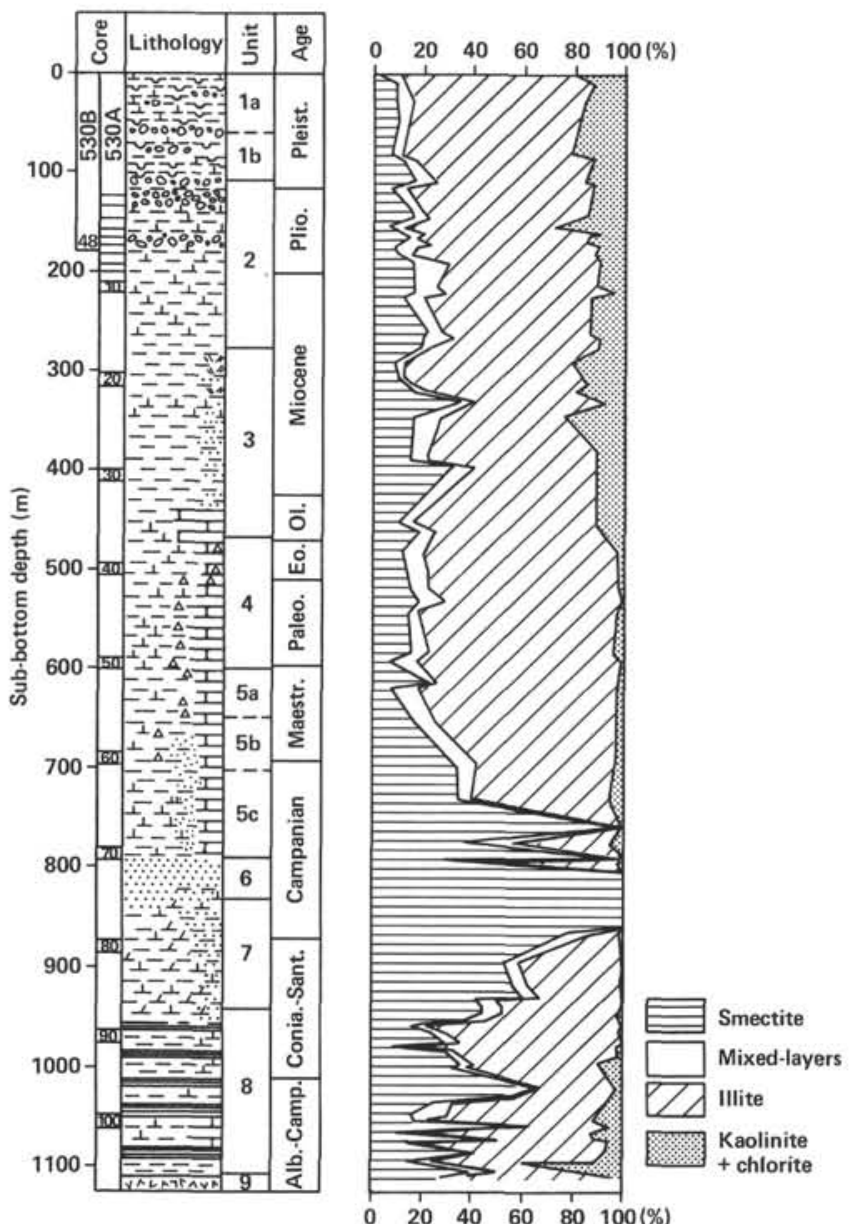

Figure 3. Clay mineralogy of representative lithologies through Site 530 , showing relative percentages of the five main clay minerals in relation to the lithologic units and stratigraphy (see site summary, this volume).

is vesicular, and there are also rare microcrystalline basalt clasts. Fragments are commonly irregular, subangular, and poorly sorted.

Carbonate occurs as void-fills in glass vesicles, where it may possibly replace zeolites, or as a cement. Bioclasts include: foraminifers, mollusk shells, echinoderms, and inoceramid prisms, with red algal clasts appearing for the first time about the middle of the sequence.

Violet luminescing quartz and blue-luminescing Tiactivated feldspar are common accessories, together with a range of stable to metastable heavy minerals including glauconite, amphiboles, pyroxenes, chlorite, and various opaques.

Diagenetic features mainly concern the degradation of glassy fragments and feldspars, with possible carbonate replacement of zeolites noted above. In the coarser beds, carbonate cementation is ubiquitous, and only a single calcite cement generation is detected, with a blocky spar mosaic formed from competitive enlargement of syntaxial overgrowths on bioclasts.

\section{Carbonate Turbidites (Plates 2-7)}

Bioclast-rich carbonate turbidites first appear near the base of Unit 7 and then again in Subunit 5b (Fig. 1); in both cases they are interbedded with feldspathic sandstones and contain a variable proportion of volcanic debris. The main development, however, is in Units 5a (Plate 2, Fig. 2) and 4, where the section is dominated by carbonate turbidites that occur as thick-bedded calcarenite and calcirudite grainstones and packstones commonly grading into calcilutite wackestones. These are interbedded with thick mudstones and marlstones representing "normal" basinal sedimentation. Within the carbonate turbidites, fining-upwards graded bedding and micro-cross lamination are common sedimentary structures. Coarser turbidite bases are grain-supported and there is a rapid transition to mud-support of bioclasts in the upper laminae.

The basal zones of calciturbidites in Unit 7 are dominated by inoceramid shell prisms, with diverse foraminifers, bryozoans, possible dasyclad algae, and echinoderm fragments (Plate 6, Figs. 1, 2, 4, 5; Plate 7, Figs. 5, 6). Lithoclasts include chert, feldspathic igneous rocks, and partly degraded volcanic glass. There are abundant feldspar grains, normally showing blue luminescence but with about $5 \%$ showing the green color described above in the feldspathic sandstone section. This feldspar population continues to be common in the succeeding finingup zones, where the bioclasts are sparser and are represented by simple thin-walled two- or three-chambered foraminifers and comminuted remains of inoceramid prisms.

With cathodoluminescence, a striking variability in the diagenetic condition of the inoceramid prisms is apparent, especially in the basal parts of turbidites (Plate 6, Fig. 2). Many are uniformly dull in luminescence, whereas others show patches of brighter luminescence which are fabric selective and related to the fibrous ultrastructure of the prisms. Where sections of inoceramid shells are well preserved, they are normally poorly luminescent, suggesting that the brightly luminescing areas in isolated prisms and prism clusters result from recrystallization and/or micritization. Some of the prisms do show micritic envelopes and patches of micritization, and these micritic areas are indeed brightly luminescent. The presence of both partly degraded and fresh prisms (all of which have inverted from aragonite to calcite) suggests that some of these grains have had an antecedent diagenesis, probably in a shallow water area, and that others have been included during turbidite transport. Many of the prisms also show V-shaped fractures which are annealed by the on-site generation of calcite cement. The fractures therefore suggest a period of precementation compaction, reflected also in local stylolitization. The post-compaction calcite cement itself is uniform in luminescence, indicating constant pore-water composition during its growth.

The best-developed carbonate turbidites form a package between the base of Unit $5 \mathrm{a}$ and the top of Unit 4 
(upper Maestrichtian to Oligocene, Fig. 1). Typically the bases are grainstones or packstones dominated by poorly size-sorted solenoporacean red algae, attended by echinoderm fragments, diverse bryozoans, mollusk shell fragments, inoceramid prisms, foraminifers, ostracods, and annelid tubes. (Plate 3, Figs. 4, 5; Plate 4, Figs. 1-3). Accessory grains include wackestone extraclasts and rounded basalt volcaniclasts (Plate 3, Fig. 6), as well as rounded glauconites and organic fluorapatites. Some turbidites, in Units $5 \mathrm{a}$ and $5 \mathrm{~b}$, where they are associated with feldspathic sandstones, also contain large fresh feldspars of which about $5 \%$ are green in luminescence. These probably share the unstable plutonic source mineralogy of the intermixed feldspathic sandstones.

With cathodoluminescence, a variety of diagenetic fabrics can be clearly demonstrated (Plate 6; Plate 7, Figs. 1-4). Some algal grains are extensively micritized but their zoecial structure is revealed in luminescence. Extremely fine, brightly luminescing cement fringes occur lining the cells on some grains; others are bored or fractured. Some grains bear eroded and micritized remnants of former isopachous fibrous cements which have clearly been inherited from the site of origin (Plate 4, Fig. 1) and have none of the characters of cements formed later at the depositional site.

Foraminifers are variously degraded: some are brightly luminescent with bright fibrous fringe cements lining their lumen and mural pores; others are poorly luminescent and have partial glauconite or mud fills of their chambers. Bryozoans are recrystallized to varying degrees or are micritized; their zooecia are often mudfilled or packed with comminuted bioclasts. Echinoderm grains also show great variability in preservation. The most degraded ones have complete or partial micrite coats and micrite-filled microborings, and show brightly luminescent microdolomite inclusions; others are fresher and poorly luminescent (as are fresh Recent echinoderm grains). Some echinoderms show partial syntaxial overgrowths which are turbid with microdolomite inclusions (Plate 4, Fig. 6; Plate 6, Figs. 4-5; Plate 7, Figs. 1-4); these microdolomites luminesce brightly. Lohmann and Meyers (1977) suggested that such cements represented former high-magnesium calcites, and Meyers and Lohmann (1978) later proposed them to be indicative of marine mixing-zone cementation.

The great variety in diagenetic alteration of the bioclasts supports the faunal evidence that many of them were derived from shallow water areas where they underwent micritization, neomorphism, and cementation before being eroded and transported to the present site of deposition together with their inherited diagenetic histories. Other grains appear to have been picked up en route during the course of turbidite travel. Bioclasts therefore show a mixture of different diagenetic histories, related to both their shallow and deeper-water origins.

Post-depositional diagenesis proceeded mainly with cementation. In samples from Unit 4 , this involved formation of sharply zoned overgrowths of clear calcite (Plate 6, Figs. 3-5; Plate 7, Figs. 1-4). These zones reflect true growth surfaces of competing crystals and pre- sumably indicate fluctuations in pore water composition. It is notable that these zoned cements are only well developed in the grainstones and packstones with their greater porosity; they are restricted and much smaller in the muddier upper parts of turbidites. The substrate selectivity of the zoned cements is also clearly apparent (Plate 7, Figs. 2, 4): They are best developed as overgrowths on echinoderms and inoceramid prisms, but they are not developed on any of the algal grains. On less crystallographically well-organized substrates such as mollusk shells, foraminifers, or bryozoan zooecia, they occur mainly as internal void-fills in a thin or condensed development.

Apart from the evidence of precementation compaction fracturing described above, the packstone/grainstone bases of the calciturbidites were also subject to considerable postcementation compaction (Plate 4, Fig. 2; Plate 6, Fig. 3; Plate 7, Figs. 3-4). In transmitted light, this is apparent from stylolitic interpenetration of bioclasts with other bioclasts or volcaniclasts. With luminescence, it becomes clear that the compactive phase indeed postdates the major episode of cementation, as the impacting grains cut across the cement growth zones.

Later diagenetic changes include some chalcedonic replacement of bioclasts and minor dolomitization of overgrowth cements (Plate 4, Fig. 3 and 6).

Finer-grained calciturbidites, or the upper portions of thick, coarse turbidites, range texturally from wackestones (Plate 3, Figs. 1-3; Plate 5, Figs. 1-2) to mudstones. The bioclast content of these units is similar to that of the grainstones described above, but on the average the grains tend to be more degraded by micritization. There are similar types of diagenetic histories inherited from prior shallow-water deposition, and the cement phase is the same, appearing as a moderately luminescent microspar in the matrix, and as blocky spar in internal voids of fossils. The effects of compaction are not so noticeable, because of the presence of supporting matrix, but extensive microstylolitization is present.

In between turbidite beds, and grading up from their tops, are spicular foraminiferal wackestones and mudstones (Plate 4, Fig. 4) with radiolarians, accessory inoceramid prisms, feldspar, and quartz. These represent the fine "tail" of the turbidite together with the succeeding interval of background pelagic sedimentation.

\section{Pelagic Clays and Silts}

Carbonate disappears rapidly near the base of Unit 3, and is replaced by a red and green pelagic clay sequence. Thin siltstones within the unit are either quartz-rich (up to $85 \%$ ) with minor clays and feldspars, or volcanogenic grains (up to $70 \%$ ) with more clay, quartz, feldspar, and other accessory minerals. More rarely, there is up to $25 \%$ resedimented carbonate debris (including pelagic foraminifers) in the silty layers.

\section{Biogenic Turbidites}

Although much of Units 2 and 1 are made up of resedimented medium to very thick-bedded turbidites and debrites, there are no distinct sand beds. The turbidites 
are muddy and biogenic and the debrites comprise mud, marl, and ooze clasts in a smarl matrix. There are dispersed sand-silt grade bioclasts throughout and concentrations of both terrigenous and biogenic sandy or silty material near the base of individual turbidites.

Unit 2 shows a marked upward trend from more terrigenous near the base (quartz and clays) to more biogenic (nannofossils, foraminifers, and diatoms) towards the top. The overlying Subunit 1b comprises 50-60\% diatoms, minor other siliceous microfossils (radiolarians, sponge spicules, silicoflagellates), about $20 \%$ clays and minor to trace amounts of calcareous bioclasts, quartz, volcanics, pyrite, and other minerals. Subunit 1a is equally rich in biogenic material $(60-80 \%)$ but with diatoms being replaced upwards by nannofossils and foraminifers, and similar but rather less clays and accessory minerals. Organic matter increases upwards through Unit 2 and is relatively high throughout Unit 1 . Total organic carbon measurements are between 1 and $6 \%$ (Meyers, Brassell, and Huc, this volume).

\section{CLAY MINERALOGY}

\section{Results}

The major variations in clay mineralogy through $1100 \mathrm{~m}$ of section at Site 530 are shown in Figure 3. Smectites comprise $10-60 \%$ of the clays in the lowest $160 \mathrm{~m}$ (lithologic Unit 8) with several marked fluctuations in abundance. In the overlying $240 \mathrm{~m}$ (Units 7 , 6 , and 5c) smectites increase significantly to nearly $100 \%$ in Unit 6 and then decrease again to around $35 \%$. Through the rest of the section (Units $5 b, 5 a, 4,3,2$, and 1) they average only $10-15 \%$ with minor fluctuations to nearly $40 \%$ in Unit 3 . Irregular mixed-layer clays are nearly always present in small amounts (2$10 \%$ ) although there appears to be less or none in sediments where the proportion of smectite is particularly high (Units 7 to $5 b$ ).

Apart from the high smectite zones, illite is the most dominant clay mineral throughout. In Unit 8, it varies between $35 \%$ and $75 \%$ and is co-dominant with smectite. Illite decreases to $0 \%$ by the middle of Unit 7 and then increases rapidly to a maximum (up to $80 \%$ ) in Units $5 \mathrm{a}$ and 4 . The amount of illite remains high but variable $(50-70 \%)$ through the rest of the section.

Kaolinite and chlorite are shown together in Figure 3. They decrease rapidly throughout Unit 8 and are absent or only present in trace amounts through Units 7 and 6. In Units 5 and 4 they are very low (1-4\%) showing a gradual but irregular increase through the rest of the section to a combined maximum of over $20 \%$ in Units 3 to 1 . Separation of the chlorite-kaolinite peaks by the slow-scan method, or removal of kaolinite by heating, shows that chlorite is dominant in the lower half of the hole, whereas kaolinite increases upwards and becomes more abundant than chlorite in the upper units (see also Maillot and Robert, this volume).

The other mineral species measured in the $<2 \mu \mathrm{m}$ fraction were very variable in absolute amounts, but certain mineral ratios (based on peak heights) showed systematic trends. The quartz/feldspar ratio $(\mathrm{Q} / \mathrm{F})$ (quartz peak at $20.85^{\circ} 2 \theta$, sum of orthoclase, and plagioclase peaks between 27 and $28^{\circ} 2 \theta$ ) varies almost inversely with the combined kaolinite-chlorite abundance. Through Unit 8, the Q/F decreases upwards; it is low in Units 7 to $5 \mathrm{~b}$, and then variable but with a slight upward increase through the rest of the section. The orthoclase/ plagioclase ratio $(\mathrm{O} / \mathrm{P})$ is higher, with slight fluctuations, towards the base (Unit 8) and decreases very slowly upwards to a low point in Unit 3.

Calcite was a common component of the clay-size fraction throughout most of the section. Its percentage of the total sediment is best shown by the direct carbonate bomb measurements (site chapter 530, this volume), or by direct geochemical measurements (Dean and Parduhn, and Maillot and Robert, this volume). High percentages of calcite, sometimes masking any clay minerals present, characterize the resedimented carbonates of Units $5 \mathrm{a}$ and 4 , and the resedimented pelagic ooze of Units 2 and 1 . By contrast, it is low to absent throughout much of Units 8 and 3. Dolomite was recognized more rarely and no systematic trends were noted. Pyrite was present in small to trace amounts in a few samples, particularly from Unit 8.

The clay mineral attapulgite, although recognized in small amounts throughout by Maillot and Robert (this volume) was only rarely identified with any degree of certainty in this study from a few Unit 4 samples.

\section{DISCUSSION}

Most of the coarser-grained clastics and carbonates cored at Site 530, as well as much of the biogenic and muddy sediment in Units 2 and 1 have been redeposited after transport from shallower water, mainly by turbidity currents. The samples used for the clay mineralogy were taken from both these coarser-grained turbidites and from the interbedded mudstones and marlstones throughout the post Albian section.

The main factors that have acted to control the turbidite petrology as well as the type and distribution of clay minerals were as follows:

1) The type of sediment in the original and transitional source areas;

2) The tectonic and volcanic history of the Angola Basin and its margins;

3) The circulation pattern, resedimentation process, and depositional environment in the basin;

4) Climate and paleolatitude; and

5) diagenetic changes.

The relative importance of these different factors on the primary mineralogy and petrology is discussed below in terms of the stratigraphic evolution at the site and subsequent diagenetic changes. We note that there is some correspondence with results from earlier Angola Basin and Walvis Ridge DSDP sites $(362,363$, and 364; Bolli, Ryan et al., 1978), but that significant differences exist (Matsumoto et al., 1978; Siesser and Bremner, 1978). Clearly, regional effects are pronounced even within the same basin and margins. Although our clay mineral data are substantially similar to those of Maillot 
and Robert (this volume), our weighting factors in quantification and our interpretations of smectite origin differ.

\section{Stratigraphic Evolution}

During Albian to Coniacian times (Unit 8) the hinterland (?African mainland) apparently enjoyed a warm equable climate, and the Angola Basin was relatively narrow and its circulation restricted (van Andel et al., 1977; LePichon et al., 1977; Arthur and Natland, 1979). Deep continental weathering produced a mixed clay assemblage in which smectite and illite were co-dominant (Chamley and Robert, 1979; Maillot and Robert, this volume) but show marked fluctuations in relative proportions. High smectite horizons may be related to postdepositional alteration of volcanogenic material. The high chlorite and high $\mathrm{Q} / \mathrm{F}$ ratio towards the base of the unit are related to a specific influx of fine-grained quartz-silt turbidites. There is little detectable difference between the black, red, and green mudstone lithologies throughout Unit 8, apart from the consistent association of pyrite and low carbonate in the black shales.

The climate and weathering regime probably remained similar through the Santonian and Campanian (Units 7, 6 , and $5 \mathrm{c}$ ) but circulation was no longer restricted. From this period until the Oligocene there is a continued input of carbonate, mainly transported from shallow marginal areas but partly derived from planktonic and benthic carbonate production in the basin. This general carbonate background was diluted during the Santonian to early Maestrichtian (Units 7 to 5c), first by an influx of feldspathic sandstones, later by volcaniclastic sandstones, and finally by more feldspathic sandstones. At all times during these incursions, the bioclast content of the clastics and of intercalated carbonate turbidites remains consistent and suggests derivation from shallowwater platform areas developing both on the African continental margin and around emergent portions of the Walvis Ridge.

The influx of feldspathic sandstones in the lower part of Unit 7 results from the tapping of a different source. The abundance of feldspars, their relatively large size and presence of microcline suggests a continental origin rather than a source from the Walvis Ridge volcanics. The quartz grains are not polycrystalline, and taken with their angularity and elongate shape, this does not indicate a metamorphic source. They also show a cathodoluminescence appropriate for an igneous and not a metamorphic origin. The quartz grains appear to be too large for a volcanic ash source (B. J. G. Upton, pers. comm.), and a plutonic source is therefore most likely. Considering the accessory zircon and often abundant biotite, the feldspathic sandstones therefore contain an unstable and highly immature assemblage which probably was derived from a granodiorite or adamellite source on the African Mainland.

The same assemblage is found in the feldspathic sandstone in Unit $5 \mathrm{~b}$, and the presence at both horizons of about $5 \%$ of the characteristic green-luminescing feldspars suggests derivation from the same source area.
Although the source of the feldspathic sandstones is reasonably certain, the manner of both their erosion and transport is less so. Apart from their extreme immaturity, the feldspar grains are very fresh and angular, as are the quartz grains. Both erosion and transport must have been extremely rapid. It is possible that sudden tectonic movements unroofed a pluton, which was subject to very rapid erosion and rapid transport over a short distance by rivers which deposited the unweathered material directly into the sea, where allied tectonic movements triggered the mixing of this material with bioclasts, followed by transport and deposition by turbidity currents. Whatever the explanation, it seems likely that the deposit has its ultimate origin in tectonic activity on the African mainland.

Volcanic and tectonic activity were also important on the Walvis Ridge during the Santonian-Campanian (Goslin and Sibuet, 1975). During this time period, it seems that the volcanic debris, including rounded basalt clasts, hyaloclastites, and degraded glass, spent some time being sorted and fragmented in shallow water, possibly around emergent islands, prior to its resedimentation downslope as volcaniclastic sands. Bioclasts, including solenoporacean red algae, were also brought down from shallow water and others picked up en route; the different provenances of bioclasts may be distinguished by their different inherited diagenetic features.

The complete dominance of smectite in the clay fraction is very clearly related to the alteration of this volcanic material. Alteration probably occurred both prior to resedimentation and during post-depositional diagenesis. Relatively high feldspar values (low $\mathrm{Q} / \mathrm{F}$ ratio) are probably also influenced by the volcanic source. The feldspars derived from the volcanics are very small and lathlike, compared with those from the continental intrusives in the feldspathic sandstones above and below the volcaniclastic sand package. Pelagic interbeds and some of the finer-grained turbidites within this package show a more mixed, continentally derived clay assemblage similar to that of Unit 8, emphasizing that contributions to the basin were being made both from the African mainland as well as the Walvis Ridge throughout the section.

The early Maestrichtian (Unit 5b) witnessed a rapid transition from volcanogenic turbidites and continentally derived feldspathic sandstones mixed with carbonates to establishment of a dominantly carbonate depositional regime. The sharp decline of the smectites here presumably reflects the decreasing influence of the Walvis Ridge. Increased oceanic circulation probably served to homogenize the mainly detrital clay assemblage, which is dominated by illite. Feldspars, micas, and quartz grains in the Maestrichtian carbonate turbidites are those characteristic of continental intrusives, with their characteristic proportion of large, green luminescent feldspars.

From the Maestrichtian to the Eocene, the diversity of shallow-water bioclasts reached a peak, with solenoporacean red algae, bryozoans, and warm-water benthic foraminifers being very abundant. This clearly shows the development of an African marginal carbonate plat- 
form comparable to those inferred around emergent areas of the Walvis Ridge. There are no traces of scleractinian or undoubted rudist bivalve grains, nor of oolites or intertidal laminites, and therefore no evidence of the existence of rudist or coral reefs and attendant backreef facies. Schlanger and Konishi (1975) demonstrate in their regional facies model that red algal-bryozoan assemblages are characteristic of areas higher in latitude than about $23^{\circ}$, with hermatypic coral-green algal assemblages found in lower latitudes. We believe, therefore, that latitudinal climatic constraints precluded the development of coral (or rudistic) reefs on the fringing platforms during this period.

The carbonate turbidites of Units $5 \mathrm{a}$ and 4 span the latest Maestrichtian and Paleogene, but show no particular lithological or mineralogical change across the Cretaceous/Tertiary boundary. This is in contrast to the mineralogical changes suggested by Chamley and Robert (1979).

The overlying Oligocene to Recent section (Units 3, 2 , and 1) has a relatively uniform clay mineralogy consistent with an open ocean circulation and an illitedominated detrital mineral suite derived from continental weathering on the African mainland. There are, however, slight but systematic trends and marked oscillations in the relative proportions of clays that can be variously explained. High smectite peaks in Unit 3 correlate with volcanic-rich horizons and are again interpreted as mainly authigenic volcanic alteration products. The appearance of kaolinite for the first time at the base of Unit 3 and its upward increase reflects the growing influence of low-latitude weathering-the combined effects of southerly directed ocean circulation and northward drift of the African plate. Illite and quartz (Q/F ratio) also increase upwards, whereas smectite and mixed layer clays decrease slightly. The effects of climatic oscillations during the Plio-Pleistocene are not detected in the clays at Site 530 .

The rapid disappearance of calciturbidites at the base of Unit 3 is concurrent with the decline of background (pelagic) carbonate to almost zero (Dean et al., this volume). The absence of carbonate from the pelagic red and green mudstones is presumably due to a raising of the CCD during the Oligocene (van Andel et al., 1977). This event is most likely related to a global rise in sea level (Vail et al., 1977) which had the additional effect of drowning carbonate platforms on the Walvis Ridge and African margin and hence cutting off resedimented carbonates from the Angola Basin. Sediment derived from the African continent was probably trapped on broad flooded continental shelves. In addition, northward drift had taken this part of the hinterland into desert latitudes so that sediment supply was further diminished.

The occurrence of both quartz-rich and volcanic-rich thin sandstones in Unit 3 may again reflect turbidite derivation from two distinct sources, the continent and the Walvis Ridge respectively. However, clear turbidite structures are rare or absent and two further possibilities exist for the origin of the volcanogenic siltstones. Either they are submarine volcanic tuff horizons or they are "sandy" contourites concentrated by the winnowing action of bottom currents (Stow and Lovell, 1979). The presence of hiatuses in the record at Site 530 in the early part of this period may result from bottom current erosion, and hence support the latter interpretation.

At the beginning of the late Miocene, the CCD was evidently lowered once more and calcareous biogenics began to accumulate, perhaps accompanied by a rise in plankton productivity. The sequence in Units 2 and 1 represents the progradation of the brown fan into the Angola Basin (Stow, this volume). The sediments are either pelagic oozes or redeposited biogenic turbidites and debrites derived from an equivalent pelagic sequence on the Walvis Ridge. The upward increase in biogenic compounds, diatoms in particular, which reach a maximum in Unit $1 \mathrm{~b}$, closely reflects the development of the Benguelan upwelling circulation and plankton productivity (Site 532 summary, this volume; Bolli, Ryan et al., 1978). It appears that the quartz-clay muddy turbidites in the lower part of Unit 2 form an integral part of the brown fan sequence, in which case we must postulate sufficient accumulation of wind-blown or volcanic quartz on the Ridge by mid-Miocene times to account for its presence in the upper Miocene turbidites at Site 530 .

\section{Diagenetic History}

There is little evidence of inorganic diagenesis in the top 200-300 m of unconsolidated sediments. Organic changes, iron sulfide/pyrite authigenesis and pore water geochemistry in this interval and through the rest of the hole are discussed elsewhere in this volume (see, for example, site summary). In the remaining $800 \mathrm{~m}$ above basement, a number of mineralogical changes have been noted, but there appear to be no systematic depth-related trends; carbonate cements, silica replacement and clay mineral authigenesis are noted throughout. The main post-depositional changes are more closely related to facies and these are discussed below for the carbonate and volcanic dominated sections respectively. We do not concern ourselves here with the complex inorganic/organic diagenesis and geochemical mobility of the organic-rich sediments in Unit 8 (but see Dean et al., this volume).

Within the carbonates, with the aid of cathodoluminescence, we have been able to distinguish between bioclasts with inherited diagenetic histories, derived from erosion and redeposition of shallow-water deposits, and those without such a complex ancestry, which may be presumed to have been included in turbidites during the basinward transport. Most of the diagenetic processes familiar to the carbonate petrologist have been noted from Site 530 bioclasts: inversion, micritization, recrystallization, cementation, and replacement. It is of considerable significance for studies of ancient carbonates that bioclasts have been transported together with their cements, ranging from nonluminescent isopachous fringes which are probably neomorphosed shallow-water marine aragonite cements, to microdolomite-rich syntaxial cements believed to originate in marine mixing-zone diagenesis. 
The style of post-depositional carbonate cementation depended largely on the texture of the sediment. In mudstones and wackestones, microsparitic cements dominate, and coarser crystals developed only in voids within fossils. No shelter voids or other mechanically produced porosity was recorded, and cementation was rarely complete as evidenced by the fact that void spaces, notably within foraminifer and pteropod tests, remained to be filled with Araldite during impregnation. In these rocks, restricted pore water flows always produced a single generation of calcite cement of uniform composition. Volcanogenic and feldspathic sandstones also only had one phase of post-depositional cementation, based on enlargement of syntaxial overgrowths from suitable substrates such as echinoderm and inoceramid prism bioclasts. At least part of the carbonate for cementation of such sandstones may have come from pressure solution of less stable bioclasts during compaction, but no direct evidence for significant carbonate dissolution was detected. Minor corrosion of quartz grains by carbonate cement was found, however, and also local replacement by carbonate of glauconite cements in foraminiferal chamber voids.

Within the carbonate turbidites of Units 5a and 4, there is again only one generation of post-depositional cement, but this characteristically has zoned luminescence, indicating fluctuations in pore water $\mathrm{Mn} / \mathrm{Fe}$ and/or $\mathrm{Eh} / \mathrm{pH}$. The initial zone is poorly luminescent, followed by a thin bright zone, progressing to a zone of medium luminescence with subzones, passing into the uniformly luminescent zone which forms the bulk of the cement in the grainstones. This sequence has been detected in Samples 47-1, $145 \mathrm{~cm}$ and 41-1, $40 \mathrm{~cm}$, more than 50 meters apart, resembling the cement stratigraphy demonstrated in Mississippian limestones by Meyers (1974). Such an observation has considerable implications for understanding of pore water migration and needs to be studied in much greater detail.

Compaction has been an important agent in modification of porosity and influencing cementation in all the "coarser" turbidites sampled between Units 4 and 7. Microstylolitization occurs in the wackestones and syntaxial cement growth appears to have been confined to areas of grains perpendicular to the stress direction. Volcaniclasts and feldspar grains are frequently deeply sutured into bioclastic grains.

In grain-supported rocks, particularly in the coarse bases of turbidites, stylolitization is much more intense, with grains clearly cross-cutting formerly continuous growth zones in the carbonate cements. The rocks have become overpacked. Since we may assume that compactional forces were applied continuously after burial, there must have been changes in the relative importance of cementation and pressure-solution during diagenesis. Compaction first caused grain fractures which were annealed by early cementation, and subsequent cement growth was rapid enough to occlude most of the porespace and therefore prevent further fracturing. Later, after the main phase of cementation, continued compactional forces were manifested by intense stylolitiza- tion and development of overpacking at the expense of void-filling cement.

A post-cementation phase of silicification was very local and confined to susceptible bioclasts such as inoceramid shells and echinoderms. Silicification was more common, but still local, in the volcanogenic sandstones, where there is some replacement of micritic cements. A further important post-depositional change in the volcanogenic sandstones has been the rapid devitrification of glasses and degradation of volcaniclasts with the consequent authigenesis of smectite clays. This very early phase of clay diagenesis has drastically inhibited porefluid mobility within the volcanic sediments and effectively prevented any subsequent large scale changes.

In contrast to the volcanogenic sandstones, the feldspathic sandstones with their very fresh and unstable mineral assemblage must have been deposited very rapidly and "sealed" from further alteration by the early development of a carbonate cement, developed in part from their significant bioclast content.

Other diagenetic processes observed within the section have almost negligible importance. Very rare, small rhombs of dolomite replaced cement and possibly bioclasts. Authigenesis of attapulgite is probably related to carbonate diagenesis.

\section{CONCLUSIONS}

1. More than 60 (mainly) turbidite beds throughout the post-Albian section at Site 530 were studied using conventional petrographic techniques. An additional 15 samples were studied with cathodoluminescence microscopy, which revealed many aspects of composition, diagenesis, and provenance that would not otherwise have been readily seen. We believe that this is the first time that luminescence techniques have been used in extensive study of DSDP material, and we would recommend that it become used routinely. Apart from its petrographic value noted above, the method is very useful for revealing fossils in recrystallized or intractable material, and is thus a help to biostratigraphers. The clay mineralogy of about 120 samples of all lithologies was determined by X-ray diffraction.

2 . The six main components recognized include diatoms, carbonate, quartz, feldspar, volcanics, and clays; a range of minor and accessory components were also identified. The main clay minerals are smectite, mixedlayer expanding clays, illite, kaolinite, and chlorite; quartz/feldspar and orthoclase/plagioclase ratios within the clay fraction were also found to be diagnostic.

3 . The vertical distribution of these components at Site 530 characterize six distinct periods of basin evolution:

(a) Albian-Coniacian: A warm equable climate, restricted basin circulation, terrigenous input (quartz, chlorite) from the African mainland;

(b) Santonian-Campanian: Similar climate but with open circulation; carbonate platforms developed along African margin and fringing emergent areas of the Walvis Ridge. Input of feldspathic sandstone turbidites from rapid erosion of granodioritic intrusion on the African 
mainland, followed by period of major tectonic and volcanic activity on the Walvis Ridge, with redeposition of volcanogenic turbidites, now smectite dominated, to the adjacent basin.

(c) Early Maestrichtian: A transitional period between volcanogenic and carbonate turbidites with a renewed influx of feldspathic sandstones from the mainland source. Full development of a carbonate-platform, red algal-bryozoan assemblage representing latitude higher than about $23^{\circ}$.

(d) Late Maestrichtian to Eocene: A quieter period of basinal sedimentation with periodic influx of calciturbidites derived from marginal carbonate platforms on both African margin and Walvis Ridge; no lithological changes mark the Cretaceous/Tertiary boundary.

(e) Oligocene-Miocene: A very quiet period of pelagic clay (illite-dominated) accumulation below carbonate compensation depth; sea level rise and flooding of the carbonate platforms cut off the source of calciturbidites. Effects of climate deterioration and increased bottom circulation also are noted;

(f) Late Miocene to Recent: Dominated by organicrich biogenic turbidites and debrites derived from rapidly accumulated pelagic sediments on the Walvis Ridge, now under the influence of the Benguela upwelling system; increased kaolinite in the clay fraction reflects the low-latitude weathering of mainland Africa.

4. A variety of post-depositional changes have been noted in the sediments between 300 and $1100 \mathrm{~m}$ depth, but these are more closely related to facies than to depth of burial. Carbonate grains were derived with antecedent diagenetic histories, including cements, from shallow water areas. Carbonate cements developed at the site of deposition were produced in a single stage, mainly by extension of syntaxial overgrowths on suitable bioclast substrates. Compaction, leading to overpacking in grainstones and packstones, has been an important diagenetic factor. Later, minor phases of silicification, dolomitization, and clay mineral authigenesis are recorded. The volcanogenic sandstones, by virtue of their mineralogical instability, have undergone major devitrification and degradation to produce smectite clays that reduced the effect of further diagenesis.

\section{ACKNOWLEDGMENTS}

We are much indebted to our technical, drafting, and secretarial staff at the Grant Institute for their many hours of assistance. In particular, Geoff Angel carried out the X-ray diffraction work and Colin Chaplin and his team prepared the thin sections of these difficult rocks for petrographic and cathodoluminescence study. We benefited much from the advice of Professor B. J. Upton on the origin of some of the igneous material. Terry Scoffin and Steve Rainey reviewed the manuscript and made helpful suggestions for its improvement. DAVS acknowledges personal support from a NERC Research Fellowship.

\section{REFERENCES}

Arthur, M. A., and Natland, J. H., 1979. Carbonaceous sediments in the North and South Atlantic: The role of salinity in stable stratification of Early Cretaceous basins. In Talwani, M., Hay, W., and Ryan, W. B. F. (Eds.), Deep Drilling Results in the Atlantic Ocean: Continental Margins and Paleoenvironment: Washington (Am. Geophys. Union), pp. 375-401.

Biscaye, P. E., 1965. Mineralogy and sedimentation of Recent deepsea clay in the Atlantic Ocean and adjacent seas and oceans. Geol. Soc. Am. Bull., 76:803-832.
Bolli, H. M., Ryan, W. B. F. et al., 1978. Init. Repts. DSDP, 40: Washington (U.S. Govt. Printing Office).

Chamley, H., and Robert, C., 1979. Late Cretaceous to early Paleocene environmental evolution expressed by the Atlantic clay sedimentation. In Christensen, W. K., and Birkelund, T. (Eds.), Cretaceous-Tertiary Boundary Events Symposium: Copenhagen, 2: 71-77.

Frank, J. R., Carpenter, A. B., and Oglesby, T. W., 1982. Cathodoluminescence and composition of calcite cement in the Taum Sauk Limestone (upper Cambrian), southeast Missouri. J. Sediment. Petrol., 52:631-638.

Geake, J. E., Walker, G., Mills, A. A., and Garlick, G. F. J., 1971. Luminescence of Apollo lunar samples. Proc. Second Lunar Sci. Conf., 3:2265-2275.

Goslin, I., and Sibuet, J.-C., 1975. Geophysical study of easternmost Walvis Ridge, South Atlantic: Deep structure. Am. Assoc. Petrol. Geol. Bull., 86:1713-1724.

LePichon, X., Sibuet, J.-C., and Francheteau, J., 1977. A schematic model of the evolution of the South Atlantic. In Charnock, H. and Deacon, G. (Eds.), Advances in Oceanography, pp. 1-48.

Lohmann, K. C., and Meyers, W. J., 1977. Microdolomite inclusions in cloudy prismatic calcites: A proposed criterion for former high magnesian calcites. J. Sediment, Petrol., 47:1078-1088.

Machel, H. G., 1982. Cathodoluminescence of Calcites: Activator Concentrations and Environmental Interpretations: Hamilton, Canada (Int. Assoc. Sedimentol. Congr.). (Abstract)

Maillot, H., and Robert, C., 1980. Mineralogie et geochemie des sediments cretaces et cenozoiques de l'Ocean Atlantique Sud. Bull. Soc. Geol. France, 22:777-788.

Mariano, A. N., Ito, J., and Ring, P. J., 1973. Cathodoluminescence of plagioclase feldspar. Geol. Soc. Am. Abstracts (Ann. Meeting), p. 726.

Marshall, D. J., 1978. Suggested standards for the reporting of Cathodoluminescence results. J. Sediment. Petrol. 48:651-653.

Matsumoto, R., Utada, M., and H., Kagami, 1978. Sedimentary petrology of DSDP cores from Sites 362 and 363 on the Walvis Ridge and Site 364, the Angola Basin, drilled on Leg 40. In Bolli, H. M., Ryan, W. B. F., et al., Init. Repts. DSDP, 40: Washington (U.S. Govt. Printing Office), 469-483.

Meyers, W. J., 1974. Carbonate cement stratigraphy of the Lake Valley Formation (Mississippian), Sacramento Mts., New Mexico. $J$. Sediment. Petrol., 44:837-861.

Meyers, W. J., and Lohmann, K. C., 1978. Microdolomite-rich syntaxial cements: Proposed meteoric-mixing zone phreatic cements from Mississippian limestones, New Mexico. J. Sediment. Petrol., 48:475-488.

Nickel, E., 1978. The present status of cathode luminescence as a tool in sedimentology. Mineral Sci. Eng., 10:73-99.

Schlanger, S. O., and Konishi, K., 1975. The geographic boundary between the Coral-Algal and the Bryozoan-Algal facies: A paleolatitude indicator. Ninth Intl. Cong. Sedimentology (Nice), 1: $187-190$.

Siesser, W. G., 1978. Leg 40 results in relation to continental shelf and onshore geology. In Bolli, H. M., Ryan, W. B. F., et al., Init. Repts. DSDP, 40: Washington (U.S. Govt. Printing Office), 965-980.

Siesser, W. G., and Bremner, J. M., 1978. X-ray mineralogy of cores from Leg 40, DSDP. In Bolli, H. M., Ryan, W. B. F., et al., Init. Repts. DSDP, 40: Washington (U.S. Govt. Printing Office), 541-548.

Stow, D. A. V., and Lovell, J. P. B., 1979. Contourites: Their recognition in modern and ancient sediments. Earth-Sci. Rev., 14: 251-291.

Vail, P. R., et al., 1977. Seismic stratigraphy and global changes of sea level. Am. Assoc. Petrol. Geol. Mem., 26:49-212.

van Andel, Tj. H., Thiede, J., Slater, J. G., and Hay W. W., 1977. Depositional history of the South Atlantic Ocean during the last 125 million years. J. Geol, 85:651-697.

Zinkernagel, U., 1978. Cathodoluminescence of quartz and its application to sandstone petrography. Contributions to Sedimentology (8th Ed.), H. Fuchtbauer, E. Stuttgart: (Schweizerbart'sch Verlags Buchhandlung) Stuttgart,

Date of Initial Receipt: November 2, 1982 


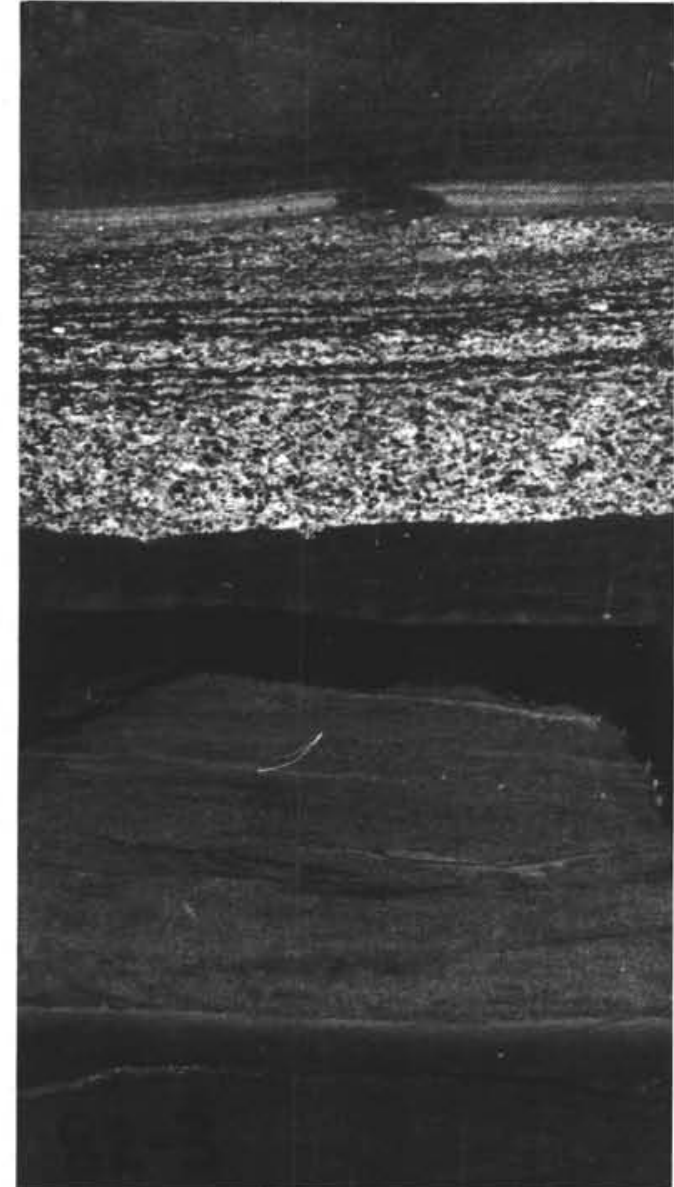

3

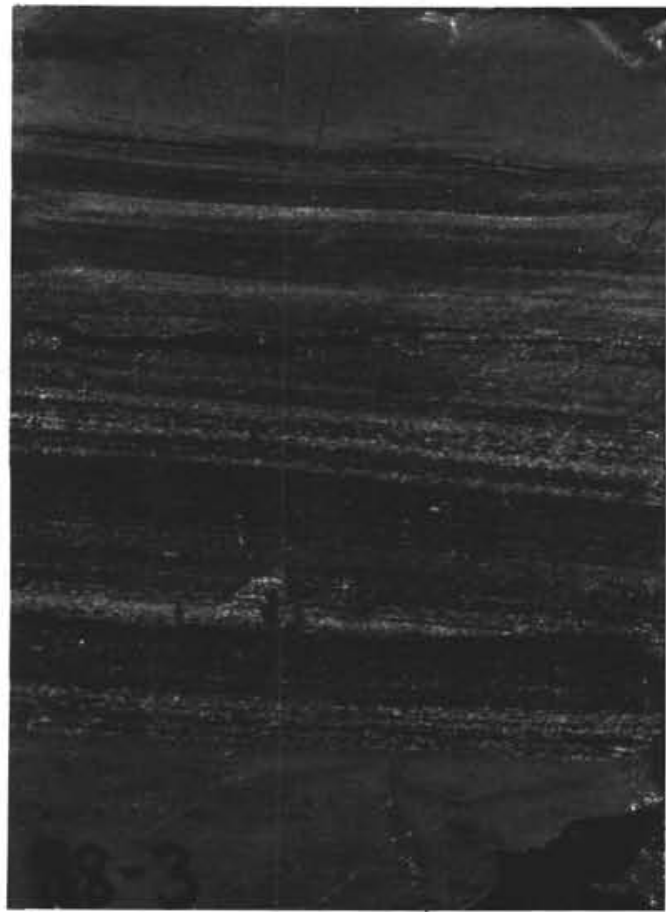

2

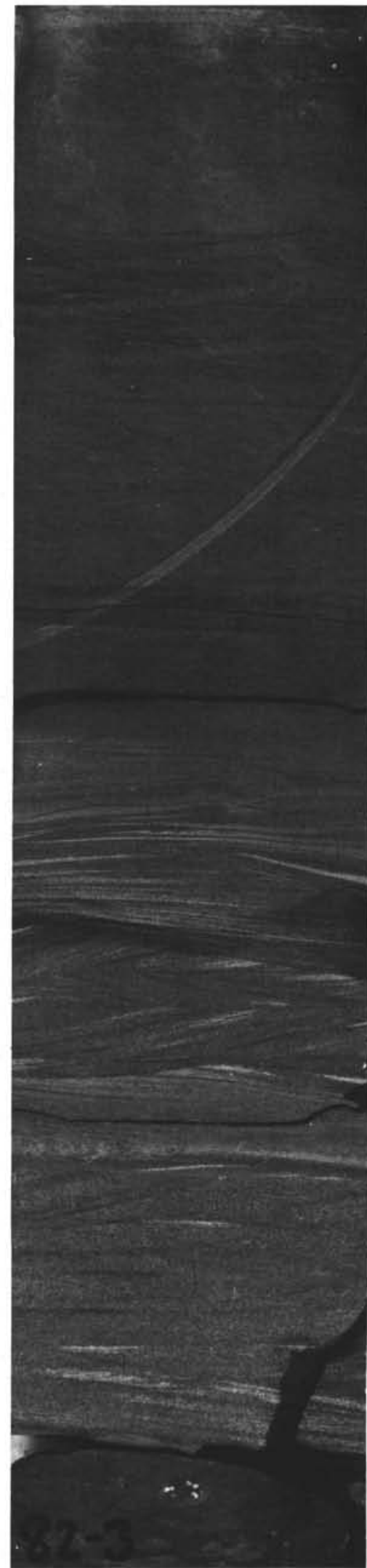

4

Plate 1. Photographs of typical turbidite facies from Hole 530A, Units 8 and 7. Width of core sections about $5 \mathrm{~cm}$. 1. Section $105-1$ (Unit 8 ), thin quartz-silt turbidites in red and green mudstones. 2. Section 88-3 (Unit 8), organic carbon-rich quartz-sand turbidites. 3. Section 82-3 (Unit 7), adjacent feldspathic (lower) and carbonate-volcanogenic (upper) turbidites. 4. Section 82-3 (Unit 7), thick graded volcanogenic turbidite. 


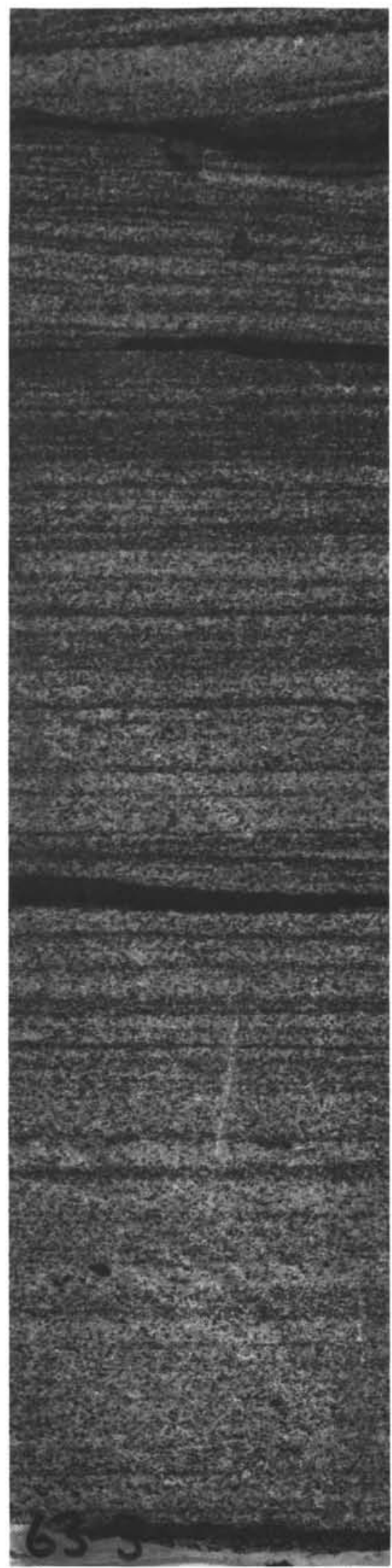

1

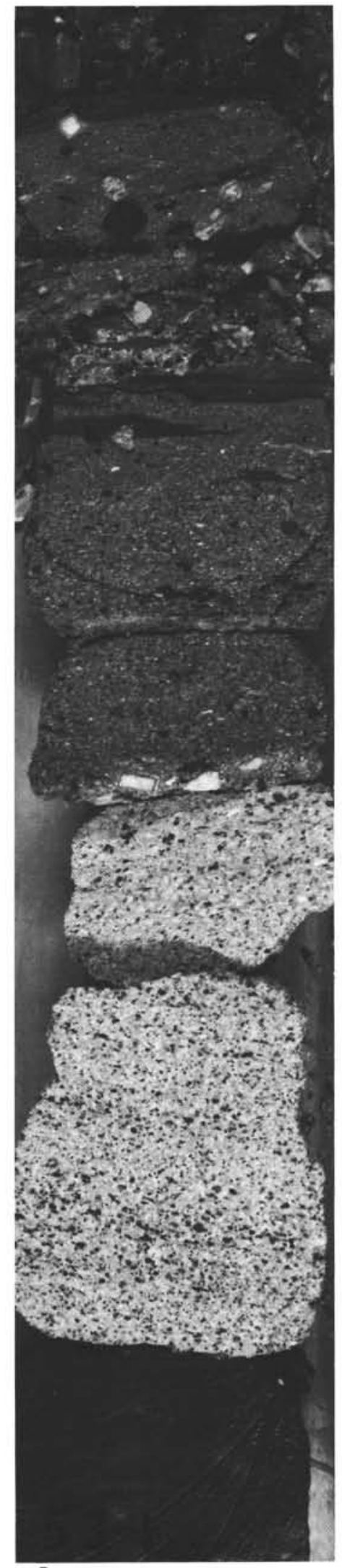

2

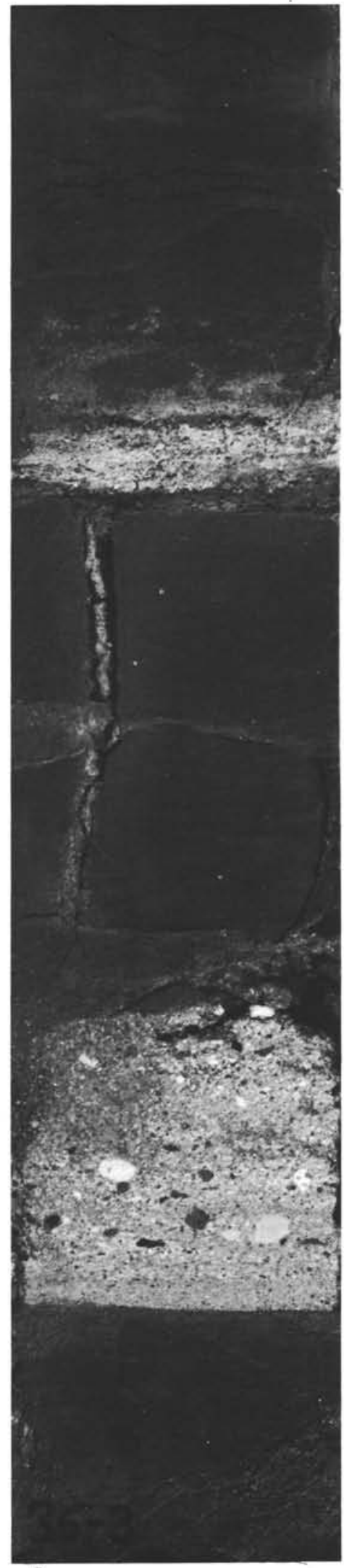

3

Plate 2. Photographs of typical turbidite facies from Hole 530A, Units 5 and 3. Width of core sections about $5 \mathrm{~cm}$. 1. Section $63-3$ (Unit $5 \mathrm{c}$ ), thick interlaminated carbonate-volcanogenic turbidite. 2. Section 52-1 (Unit 5a), calcarenite-calcirudite turbidite. 3. Section 35-3 (Unit 3), last stratigraphic occurrence of thin calciturbidites at Site 530 with red/green pelagic clay sequence. 

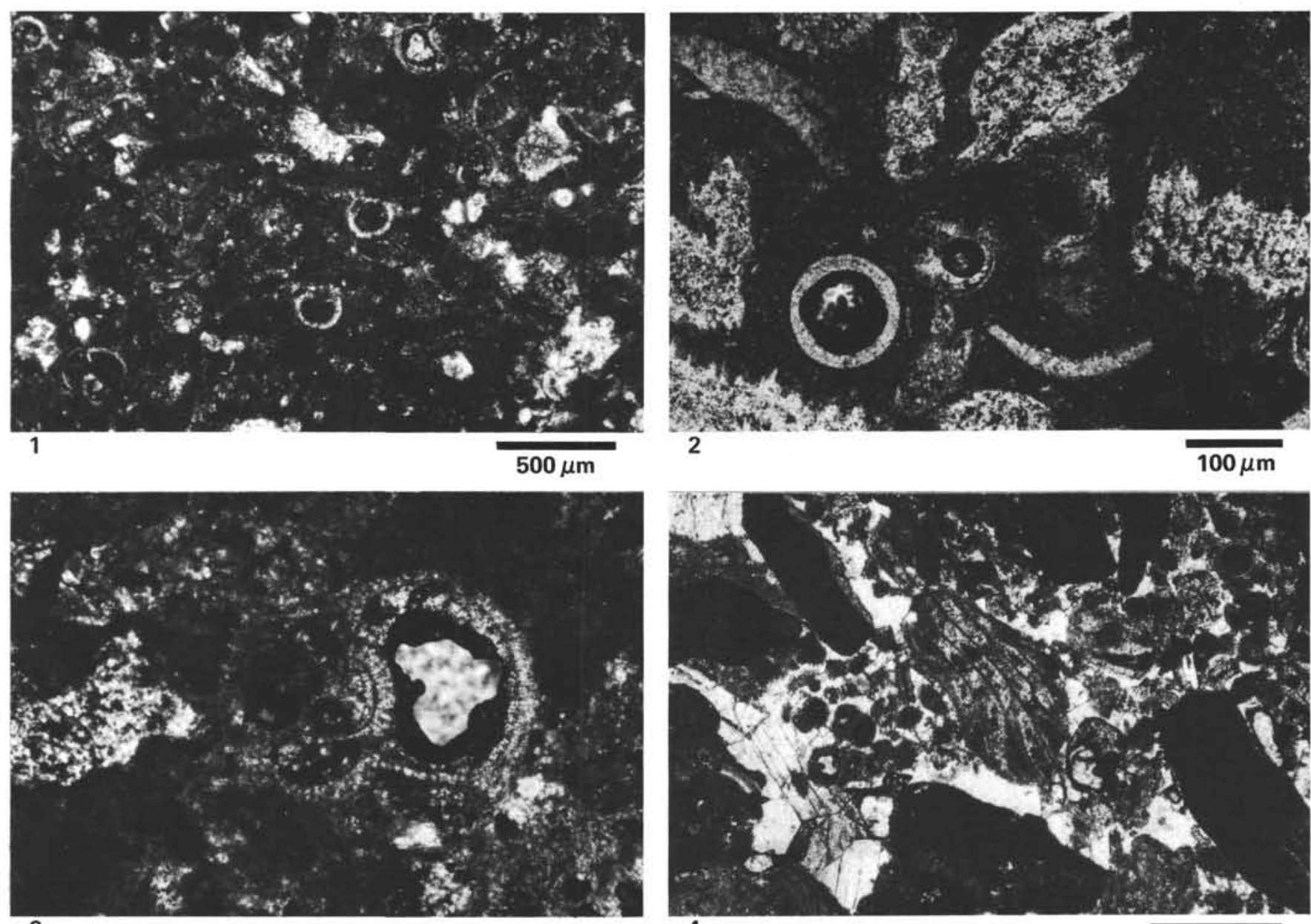

3
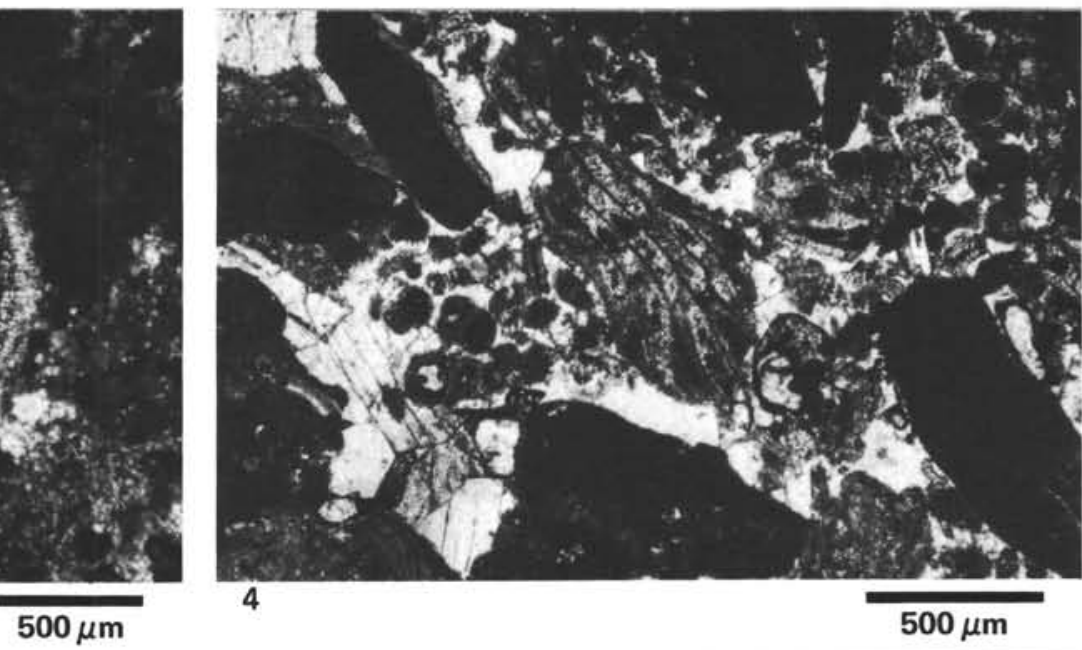

4

$500 \mu \mathrm{m}$
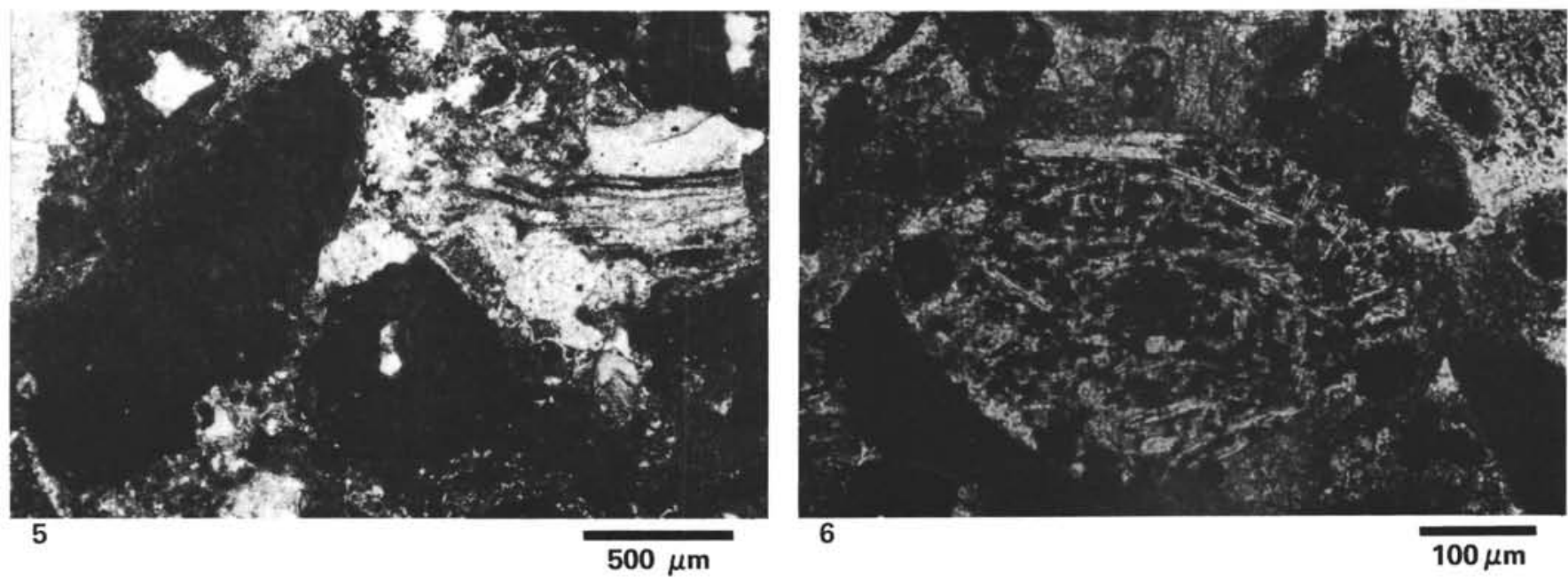

Plate 3. Plane polarized light microphotographs, carbonate turbidites from Hole 530A, Unit 4. 1. Sample 40-2, 95 cm; algal-bryozoan-echinoderm wackestone with foraminifers. 2. Sample 43-2, $138 \mathrm{~cm}$; wackestone with echinoderm grains showing ragged syntaxial cement overgrowths resulting from matrix replacement, mollusk fragments, and pteropod (air bubble in lumen). 3 . Sample $40-2,95 \mathrm{~cm}$; foraminifer with glauconite lining lumen of large chamber: rest of chamber is void. 4. Sample 47-1, $145 \mathrm{~cm}$; algal-bryozoan packstone with clear calcite cement. Note rounded algal and bryozoan clasts, some with inherited cement fringes. 5. Sample 44-2,97 cm; algal-bryozoan packstone showing cellular structure of solenoporacean algae. 6. Sample $47-1,145 \mathrm{~cm}$; rounded volcaniclast with feldspar microphenocrysts in algal-bryozoan packstone. 

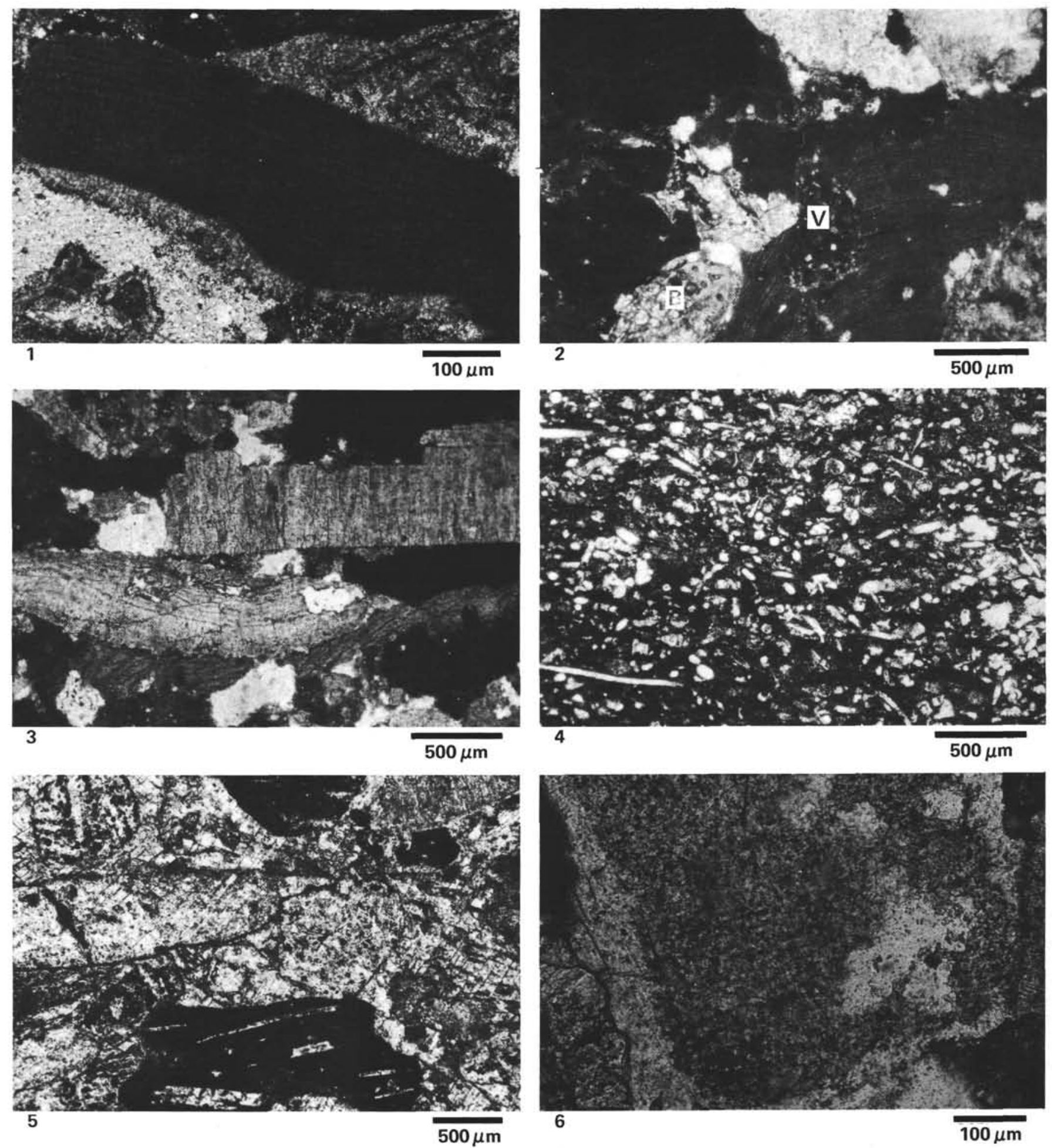

Plate 4. Transmitted light microphotographs, plane polarized except Figure 6 (crossed nichols). 1. Sample 47-1, 143 cm (Unit 4), solenoporacean red algal bioclast with relict fibrous cement crust which has been eroded and micritized. 2. Sample $51-1,121 \mathrm{~cm}$ (Unit 4), algal-bryozoan grainstone showing red algal bioclasts of two different types and stylolitic interpenetration by a volcaniclast (V) bryozoan (B). 3. Unit 4, algal-bryozoan grainstone with local concentration of abraded bivalve shells. Upper prismatic shell probably of inoceramid; middle laminated shell shows clear chalcedonic silica replacement patches; lowermost shell is intensely stylolitized. 4. Sample $51-5,61 \mathrm{~cm}$ (Unit 4), spicular-radiolarian wackestone with accessory feldspar, quartz, and inoceramid prisms. 5. Sample 67-1, $106 \mathrm{~cm}$ (Unit 5c), carbonate-rich interlamina in volcanogenic sandstones. Note the micritic envelopes around the recrystallized bioclasts and the sparry overgrowth cement. 6. Sample 51-1, 121 cm (Unit 4), echinoderm bioclast with pyrite and microdolomite inclusions and microdolomite-rich syntaxial overgrowth cement. 

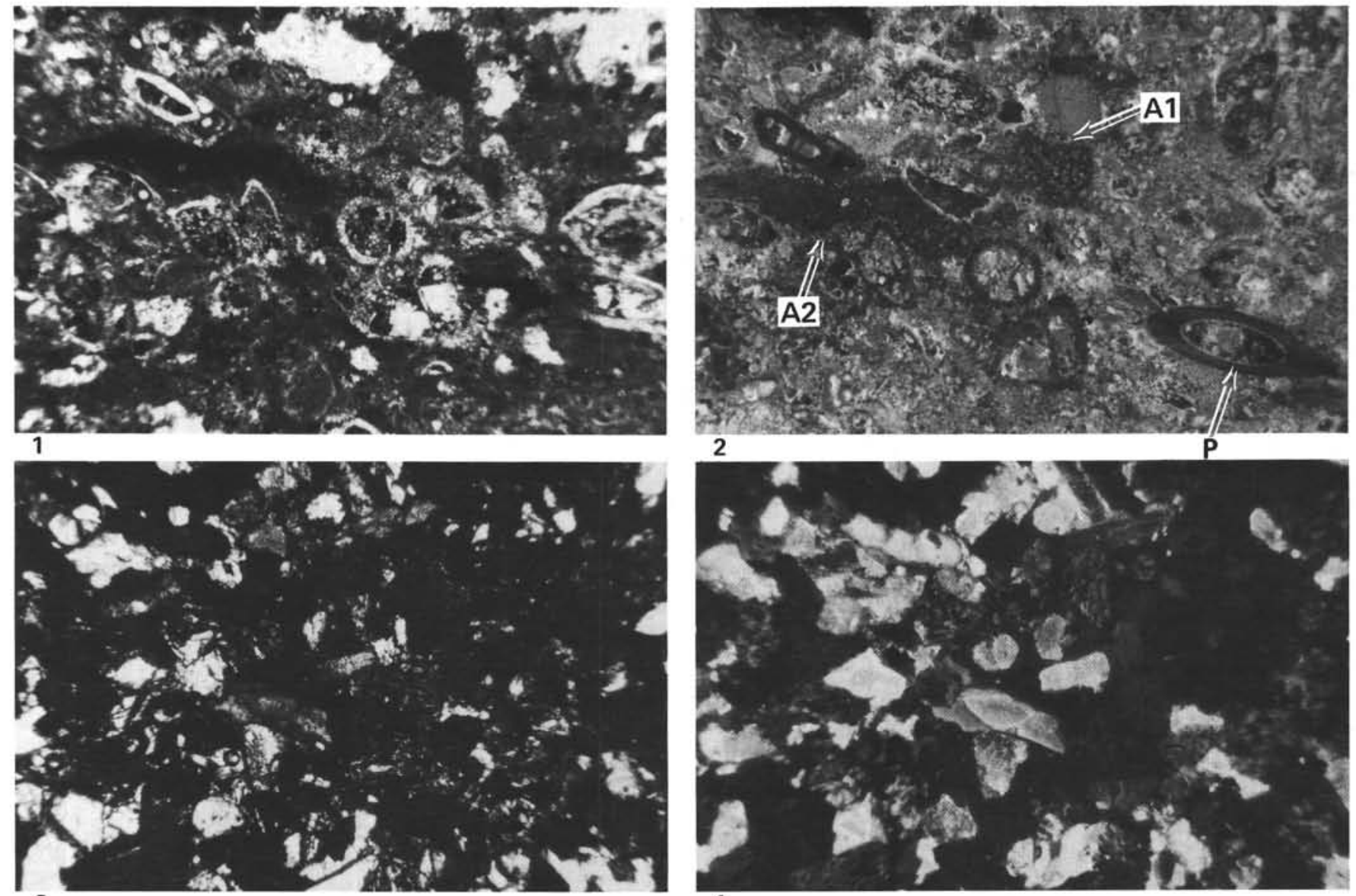

3
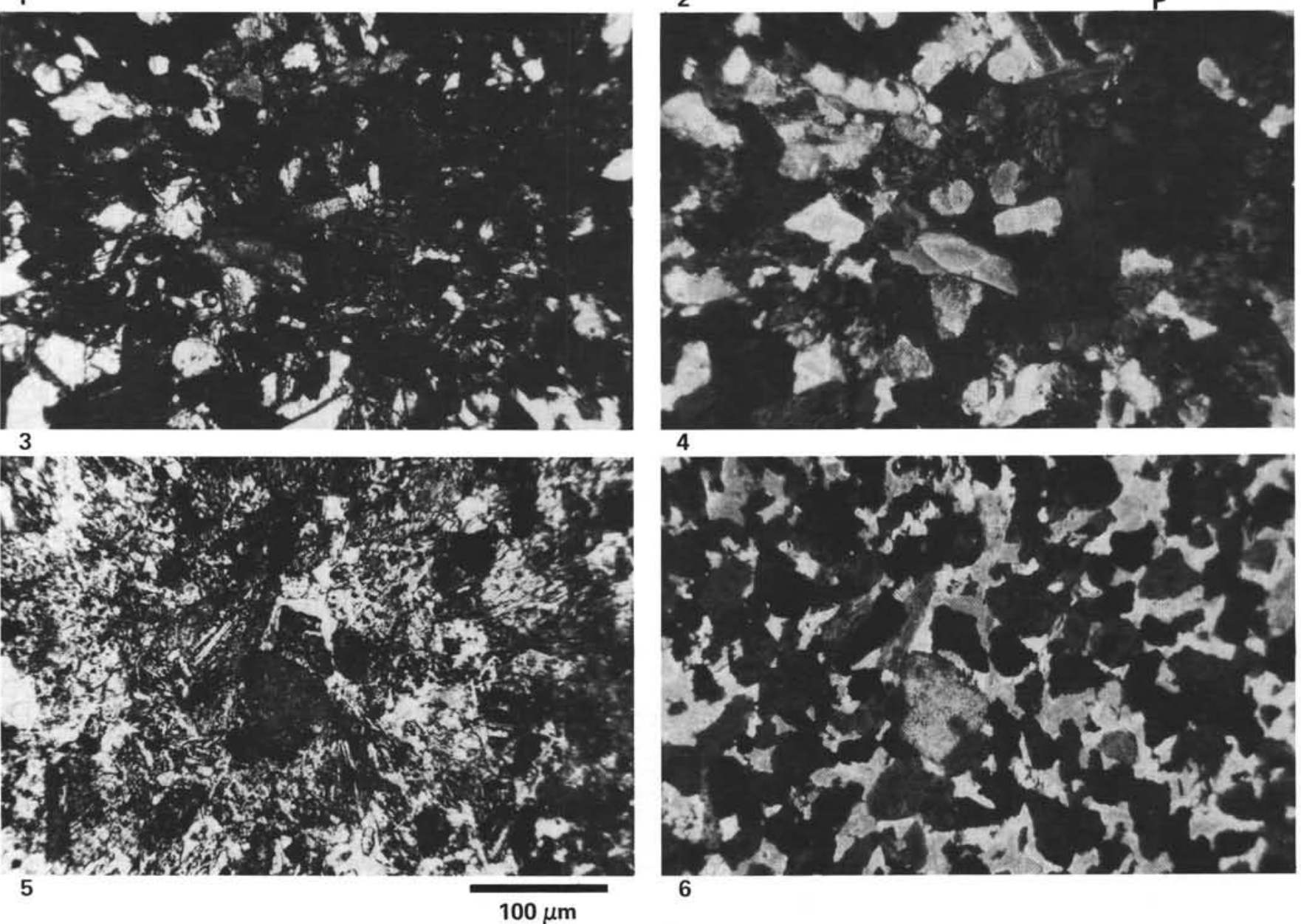

6

Plate 5. Paired microphotographs: in each case transmitted light view to left, cathodoluminescence view to right. 1-2. Sample 40-2, 95 $\mathrm{cm}$ (Unit 4), algal-bryozoan-echinoderm wackestone. Algal bioclast A1 has relict grain with bright luminescence and dark vein; A2 is poorly luminescent with thin, bright cement fringes inside cells. Foraminifers often with bright cements in mural pores. Pteropod, P, has internal bright cement fringe. 3-4. Sample 64-2, $68 \mathrm{~cm}$ (Unit 5c), volcaniclastic sandstone, inoceramid prisms, and their calcite cement overgrowths pale gray in luminescence view; feldspars and feldspathic volcaniclasts medium gray; quartz black or dark gray. These represent orange-red, blue, and dark violet luminescence colors, respectively. 5-6. Sample 67-1, $106 \mathrm{~cm}$ (Unit 5c), volcaniclastic sandstone. On Figure 6, brightest grains and areas are bioclasts and uniform sparry cement; mid-gray grains showing cleavage are feldspars and altered volcaniclasts; dark grains mostly angular quartz. Luminescence colors as in Figures 5, 6. 

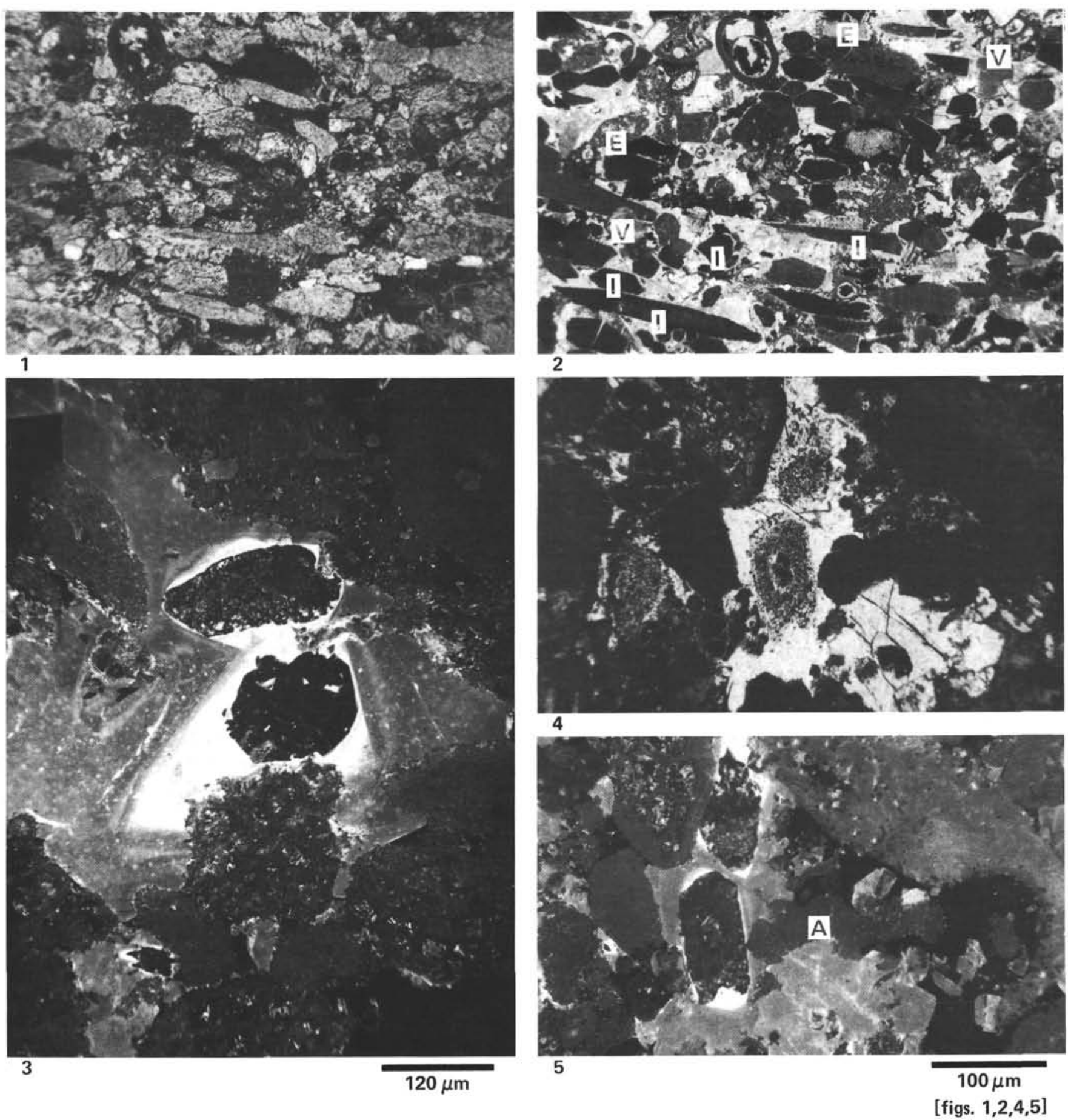

Plate 6. Figures 1 and 4, transmitted light; Figures 2, 3, and 5, cathodoluminescence. 1-2. Sample 82-2, $73 \mathrm{~cm}$ (Unit 7), grainstone base of calcareous turbidite. Note abundant inoceramid prisms (I), most weakly luminescent; recrystallized echinoderms (E), volcaniclasts (V). Foraminifer at top center has ragged, brightly luminescent internal void-fill cement of same generation as background cement. Volcaniclast towards left interpenetrates inoceramid prism. 3. Sample $47-1,45 \mathrm{~cm}$ (Unit 4), overpacked algal-bryozoan grainstone from carbonate turbidite. Composite algal lithoclast (A) and comminuted bryozoan (B) have interpenetrated the growth zones of the syntaxial overgrowth cement on two echinoderm grains. 4-5. Sample 47-1,45 cm (Unit 7), overpacked algal-bryozoan grainstone. Zoned syntaxial calcite overgrowth cement on adjacent echinoderm grains with inherited earlier cloudy microdolomite-rich overgrowth phase. Note penetration of algal grain (A) into youngest overgrowth cement. 

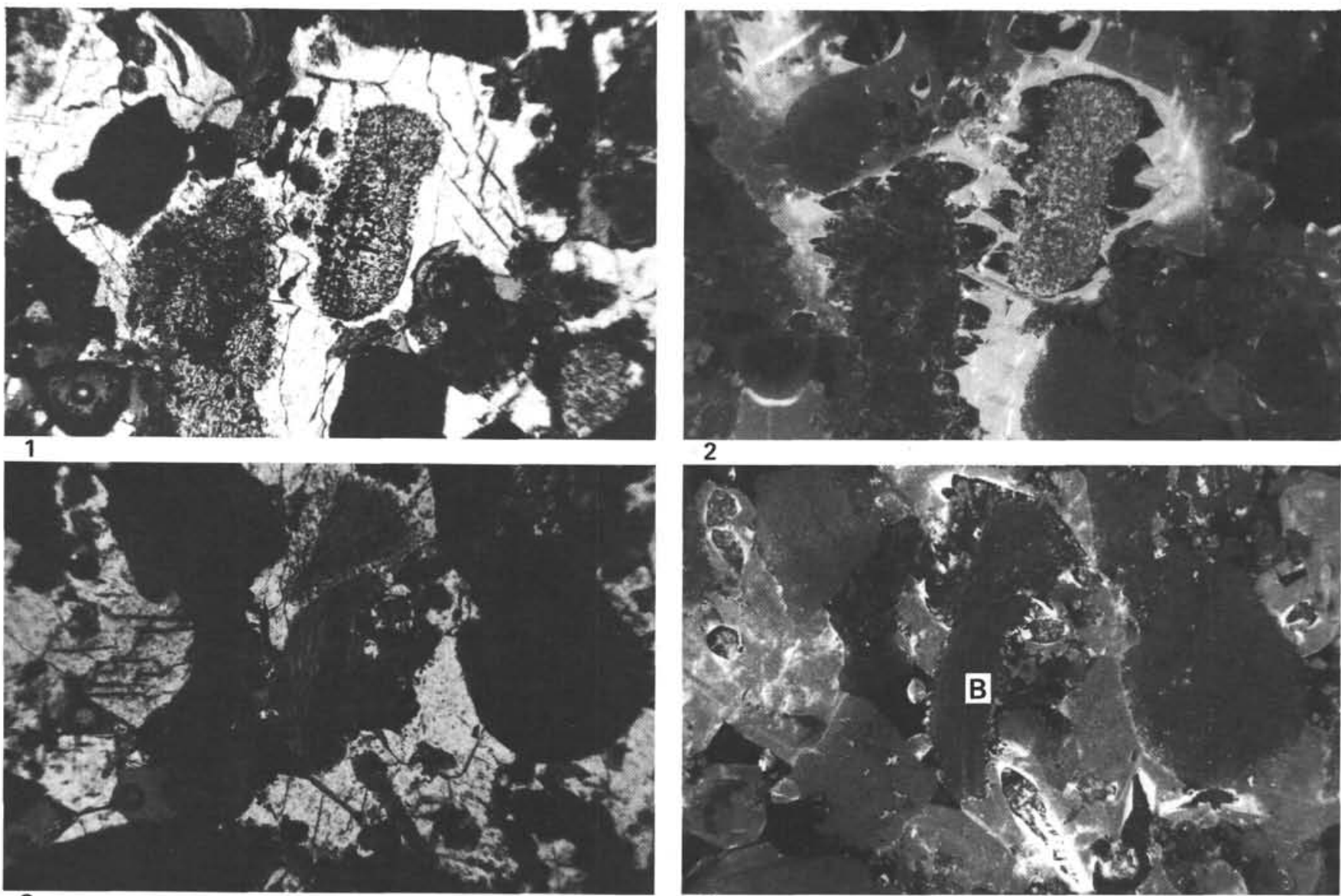

3

4
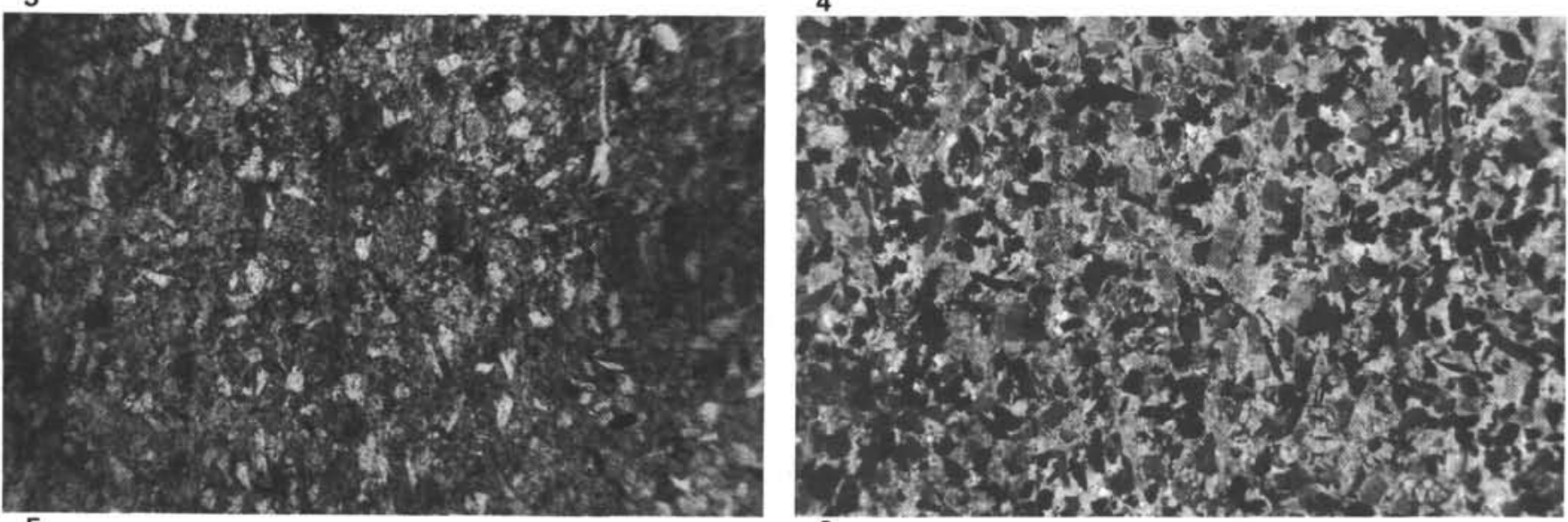

6

Plate 7. Paired microphotographs; in each case transmitted light view to left, cathodoluminescence view to right. 1-2. Sample 47-1, 145 cm (Unit 4), algal-bryozoan grainstone. Echinoderm grains with zoned syntaxial overgrowths (compare Plate 6, Figs. 3 and 5). Figure 2 shows rightmost echinoderm grain to have bright microdolomite inclusions and a thin, eroded inherited cloudy microdolomite-rich overgrowth cement with a micrite envelope. The envelope has selectively inhibited later post-depositional overgrowth cement except for where it has been abraded. Lower echinoderm grain is degraded by micritization and partial silicification. 3-4. Unit 4; algal-bryozoan grainstone. Zoned calcite overgrowth on echinoid spine (E). Cement is penetrated by bivalve fragment (B), which has a crystallographically less suitable substrate for cement growth than the echinoderm, so has a ragged cement fringe but with same cement zones. 5-6. Sample 83-1, 22 cm (Unit 7), feldspathic sandstone with (on Fig. 6) shard-like dark gray quartz grains, mid-gray feldspars and bright, uniform calcite cement with scattered bioclasts, mainly fragmented inoceramid prisms. 